Article

\title{
First-Principles Study on the Mechanical Properties and Electronic Structure of V Doped WCoB and $\mathrm{W}_{2} \mathrm{CoB}_{2}$ Ternary Borides
}

\author{
Tong Zhang ${ }^{1}$, Haiqing Yin ${ }^{2,3,4, *}$, , Cong Zhang ${ }^{2}$, Ruijie Zhang ${ }^{2}$, Xue Jiang ${ }^{2}$, Qingjun Zheng ${ }^{5}$ \\ and Xuanhui Qu ${ }^{1,2,6}$ (D) \\ 1 Institute for Advanced Materials and Technology, University of Science and Technology Beijing, \\ Beijing 100083, China; tobyzhang1992@163.com (T.Z.); quxh@ustb.edu.cn (X.Q.) \\ 2 Collaborative Innovation Center of Steel Technology, University of Science and Technology Beijing, \\ Beijing 100083, China; zhangcong@ustb.edu.cn (C.Z.); zrj@ustb.edu.cn (R.Z.); jiangxue@ustb.edu.cn (X.J.) \\ 3 Beijing Laboratory of Metallic Materials and Processing for Modern Transportation, University of Science \\ and Technology Beijing, Beijing 100083, China \\ 4 Beijing Key Laboratory of Materials Genome Engineering, University of Science and Technology Beijing, \\ Beijing 100083, China \\ 5 Kennametal Incorporated Company, 1600 Technology Way, Latrobe, PA 15650, USA; \\ jack.zheng@kennametal.com \\ 6 Beijing Advanced Innovation Center for Materials Genome Engineering, University of Science and \\ Technology Beijing, Beijing 100083, China \\ * Correspondence: hqyin@ustb.edu.cn
}

Received: 15 February 2019; Accepted: 18 March 2019; Published: 22 March 2019

\begin{abstract}
For the purpose of exploring new hard materials and doping methods, the structural, mechanical and electronic properties of $\mathrm{WCoB}$ and $\mathrm{W}_{2} \mathrm{CoB}_{2}$ ternary boride were investigated with $0,8.33,16.67,25$ and 33.33 at.\% $\mathrm{V}$ doping content and $\mathrm{W}_{2} \mathrm{CoB}_{2}$ with $0,5,10,15$ and 20 at.\% V doping content by first-principle calculations. The cohesive energy, impurity formation energy and formation energy indicate the structural stability of $\mathrm{V}$ doped $\mathrm{WCoB}$ and $\mathrm{W}_{2} \mathrm{CoB}_{2}$. The elastic constants and mechanical properties imply that $\mathrm{V}$ doping leads to the decrement of shear modulus and the increment of ductility. Two different kinds of hardness models verify that $\mathrm{V}$ doping contributes to the decrement of hardness, which is closely related to shear modulus. The electronic structure is analyzed by DOS (density of states), PDOS (partial density of states) and charge density difference, which indicate the formation of weaker $\mathrm{B}-\mathrm{V}$ covalent bonds, $\mathrm{W}-\mathrm{V}$ and $\mathrm{W}-\mathrm{W}$ metallic bonds lead to the decrement of mechanical properties. Compared with previous studies of $\mathrm{Cr}, \mathrm{Mn}$ doped WCoB and $\mathrm{W}_{2} \mathrm{CoB}_{2}, \mathrm{~V}$ doping leads to worse mechanical properties and hardness, indicating $\mathrm{V}$ may not be a suitable choice of doping transition elements.
\end{abstract}

Keywords: first-principles calculations; $\mathrm{V}$ doping; $\mathrm{WCoB} ; \mathrm{W}_{2} \mathrm{CoB}_{2}$; electronic structure

\section{Introduction}

Ternary borides, including $\mathrm{Mo}_{2} \mathrm{FeB}_{2}, \mathrm{Mo}_{2} \mathrm{NiB}_{2}, \mathrm{WCoB}$, were fabricated by reaction bronizing sintering, which solved the poor sintering property of binary borides [1]. Ternary borides are suitable substitutes for WC-Co cermet owing to their high melting point, high hardness, high corrosion resistance and high electrical conductivity [2]. For their great potential as a wear-resistant material, ternary borides have attracted scientists' attention in recent years [3-6].

Due to its outstanding mechanical properties, WCoB ternary boride has been studied for years [7-9]. Current studies of ternary borides are focused on the transition elements of doping 
to improve mechanical properties, such as $\mathrm{V}, \mathrm{Cr}, \mathrm{Mn}, \mathrm{Nb}$, etc. [10-14]. V is an important choice of transition element doping and is widely used to improve the mechanical properties of materials [15-22]. $\mathrm{Hu}$ [23] and $\mathrm{Yu}$ [24] found $2 \mathrm{wt}$ \% V doping is able to improve the hardness and transverse rupture strength (TRS) of $\mathrm{Mo}_{2} \mathrm{FeB}_{2}$ up to $87 \mathrm{HRA}$ and $1800 \mathrm{MPa}$, respectively. Shiota [25], Yamasaki [26] and Takagi [27] found V doping can improve the wettability of the $\mathrm{Mo}_{2} \mathrm{NiB}_{2}$ hard phase, hardness and TRS up to 90.8 HRA (Rockwell hardness A) and $3200 \mathrm{MPa}$. This enhancement is owed to grain refinement, decrease of porosity and increase of phase uniformity. Yamasaki [28] also found $12.5 \mathrm{wt}$ \% V doping leads to $\mathrm{Mo}_{2} \mathrm{NiB}_{2}$ phase transformation from orthorhombic phase to tetragonal phase and TRS up to $2500 \mathrm{MPa}$ with the smallest grain size.

However, experimental studies of $\mathrm{V}$ doped $\mathrm{WCoB}$ ternary boride are rare. The first-principle calculation has been widely used to explore mechanical properties and electronic structure, which can provide more information on experiments. Yang [29] and Sun [30] used first-principle calculation to find $\mathrm{Mn}$ doping improves the mechanical properties of $\mathrm{Mo}_{2} \mathrm{FeB}_{2}$ ternary boride and verified the results by experiment with the highest hardness and TRS up to $89.4 \mathrm{HRA}$ and $1290 \mathrm{MPa}$, respectively. Wang [31] and Lin [32] studied the effects of different contents of $\mathrm{Cr}, \mathrm{Ni}, \mathrm{Mn}$ doped $\mathrm{Mo}_{2} \mathrm{FeB}_{2}$ ternary boride. They found Ni doping leads to the increment of ductility and elastic modulus and Cr doping contributes to the increment of bulk modulus. Li [33] studied the different contents of $\mathrm{V}$ doped $\mathrm{Mo}_{2} \mathrm{NiB}_{2}$ by first-principle calculation and found that $\mathrm{Mo}_{1.625} \mathrm{Ni}_{0.625} \mathrm{~V}_{0.75} \mathrm{~B}_{2}$ has the lowest energy.

Because there are no reports on $\mathrm{V}$ doped $\mathrm{WCoB}$, we used first-principle calculation to explore the effect of $\mathrm{V}$ doping on benefitting the selection of a suitable doping element. $\mathrm{WCoB}$ and $\mathrm{W}_{2} \mathrm{CoB}_{2}$ are regular hard phase in WCoB ternary boride hard alloy [34], so two cases are considered: the content of V doping are 0, 8.33, 16.67, 25 and 33.33 at.\% separately in WCoB unit cell and 0, 5, 10, 15 and 20 at.\% separately in $\mathrm{W}_{2} \mathrm{CoB}_{2}$ super cell.

It is worth pointing out that the effects of different contents of $\mathrm{Cr}$, Mn doped WCoB on mechanical properties and electronic structure have been studied by first-principle calculation in our previous work $[35,36]$. We found that B-Cr, B-Mn bonds play an important role in the crystal. Nevertheless, the previous studies of $\mathrm{Cr}$, Mn doping $\mathrm{WCoB}$ is calculated by unit cell, which cannot provide sufficient details on the variation of $\mathrm{W}_{2} \mathrm{CoB}_{2}$ in different doping contents. So, the structure, lattice parameters, population, density of states and charge density difference of $\mathrm{WCoB}$ and $\mathrm{W}_{2} \mathrm{CoB}_{2}$ are studied in detail to explore their mechanical properties and hardness in different V doped structures. At the same time, the mechanical properties and hardness of $\mathrm{Cr}, \mathrm{Mn}, \mathrm{V}$ doped $\mathrm{WCoB}$ and $\mathrm{W}_{2} \mathrm{CoB}_{2}$ are also discussed.

\section{Crystal Structure and Calculation Method}

All first-principle calculations in this paper are conducted based on density functional theory (DFT) $[37,38]$ with Cambridge Serial Total Energy Package (CASTEP) code [39]. The exchange and correlation terms are described by generalized gradient approximation (GGA) in the Perdew-Burke-Ernzerhof (PBE) form. Different Monkhorst-Pack nets have been evaluated to ensure the lowest energy of different models. The interaction of the valence electrons and ionic cores are calculated with Vanderbilt ultrasoft pseudopotential. The valence states considered here are chosen as $W\left(5 s^{2} 5 p^{6} 5 d^{4} 6 s^{2}\right), C o\left(3 d^{7} 4 s^{2}\right), B\left(2 s^{2} 2 p^{1}\right)$ and $V\left(3 s^{2} 4 p^{6} 3 d^{3} 4 s^{2}\right)$. The integration over the Brillouin zone was conducted with Monkhorst and Pack k-point mesh integrations.

The space group of orthorhombic WCoB (ICSD collection code: 613390) [40] is No.62 Pnma. The Wyckoff positions of W, Co and B are $4 \mathrm{c}(0.021,0.25,0.18), 4 \mathrm{c}(0.142,0.25,0.561)$ and $4 \mathrm{c}(0.765$, $0.25,0.623)$. The lattice parameters are $\mathrm{a}=5.745 \AA, \mathrm{b}=3.203 \AA$ and $\mathrm{c}=6.652 \AA$. The WCoB unit cell that contains $4 \mathrm{~W}$ atoms, $4 \mathrm{Co}$ atoms and $4 \mathrm{~B}$ atoms with periodic boundary conductions is used, as shown in Figure 1. The effect of V doping content for WCoB is calculated by using different numbers of $\mathrm{V}$ atoms to replace Co site positions. The chemical formulae can be expressed by: (a) $\mathrm{W}_{4} \mathrm{Co}_{4} \mathrm{~B}_{4}$, (b) $\mathrm{W}_{4} \mathrm{Co}_{3} \mathrm{VB}_{4}$ (position: 1), (c) $\mathrm{W}_{4} \mathrm{Co}_{2} \mathrm{~V}_{2} \mathrm{~B}_{4}$-sy (position: 1, 4); $\mathrm{W}_{4} \mathrm{Co}_{2} \mathrm{~V}_{2} \mathrm{~B}_{4}$-unsy (position: 1, 2), (d) $\mathrm{W}_{4} \mathrm{CoV}_{3} \mathrm{~B}_{4}$ (position: 1, 2, 4) and (e) $\mathrm{W}_{4} \mathrm{~V}_{4} \mathrm{~B}_{4}$ (all position of Co atoms) by replacing $0,1,2,3$ and 4 Co atoms in WCoB unit-cell. 


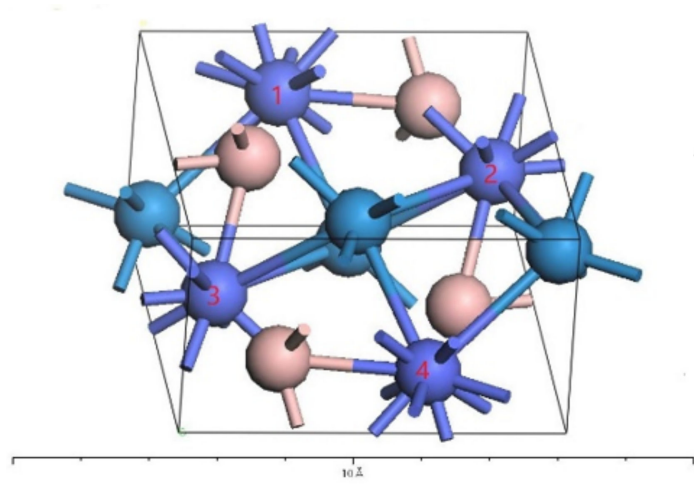

(a)

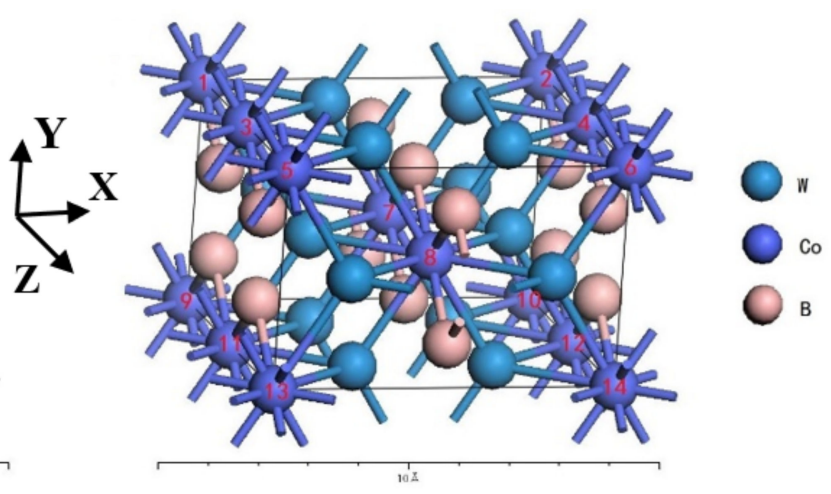

(b)

Figure 1. Orthorhombic structure of $\mathrm{V}$ doping (a) $\mathrm{WCoB}\left(\mathrm{W}_{4} \mathrm{Co}_{4-x} \mathrm{~V}_{x} \mathrm{~B}_{4}, x=0,1,2,3,4\right)$ and $(\mathbf{b}) \mathrm{W}_{2} \mathrm{CoB}_{2}$ $\left(\mathrm{W}_{8} \mathrm{Co}_{4-x} \mathrm{~V}_{x} \mathrm{~B}_{4}, x=0,1,2,3,4\right)$.

The space group of orthorhombic $\mathrm{W}_{2} \mathrm{CoB}_{2}$ (ICSD collection code: 16776) [41] is No.71 Immm. The Wyckoff positions of $\mathrm{W}, \mathrm{Co}$ and $\mathrm{B}$ are $4 \mathrm{f}(0.205,0.5,0), 2 \mathrm{a}(0,0,0)$ and $4 \mathrm{~h}(0,0.3,0.5)$. The lattice parameters are $\mathrm{a}=7.075 \AA, \mathrm{b}=4.564 \AA$ and $\mathrm{c}=3.177 \AA$. To investigate the influence of different doping content, we constructed supercell $1 \times 1 \times 2$ containing $8 \mathrm{~W}$ atoms, 4 Co atoms and $8 \mathrm{~B}$ atoms with periodic boundary conductions, as shown in Figure 1. The effect of V doping content for $\mathrm{W}_{2} \mathrm{CoB}_{2}$ is calculated by using different numbers of $\mathrm{V}$ atoms to replace $\mathrm{Co}$ site positions. The chemical formulae can be expressed by (f) $\mathrm{W}_{8} \mathrm{Co}_{4} \mathrm{~B}_{8},(\mathrm{~g}) \mathrm{W}_{8} \mathrm{Co}_{3} \mathrm{VB}_{8}$ (position: 8), (h) $\mathrm{W}_{8} \mathrm{Co}_{2} \mathrm{~V}_{2} \mathrm{~B}_{8}$ (position: 7, 8), (i) $\mathrm{W}_{8} \mathrm{CoV}_{3} \mathrm{~B}_{8}$ (position: $3,4,7,8,11,12$ ) and (j) $\mathrm{W}_{8} \mathrm{~V}_{4} \mathrm{~B}_{8}$ (all positon of Co atoms) by replacing $0,1,2,3$ and $4 \mathrm{Co}$ atoms in $\mathrm{W}_{2} \mathrm{CoB}_{2}$ super cell.

The cutoff energy of a plane-wave set was set as $600 \mathrm{eV}$ and $400 \mathrm{eV}$ to calculate electron wave function, and the k-point grid was set as $5 \times 10 \times 5$ and $3 \times 5 \times 4$ for $\mathrm{WCoB}$ and $\mathrm{W}_{2} \mathrm{CoB}_{2}$, respectively. The Broyden-Flecher-Goldfarb-Shanno (BFGS) geometry optimization task was applied to obtain a fully relaxed atomic position and a stable structure with minimum total energy [42] during geometry optimization. The convergence conditions were set as the maximum stress below $0.01 \mathrm{GPa}$, the maximum force on the atom below $0.01 \mathrm{eV} / \AA$, the self-consistent convergence of the total energy below $5 \times 10^{-6} \mathrm{eV} /$ atom and the maximum displacement between cycles below $5 \times 10^{-4} \AA$.

\section{Results and Discussion}

\subsection{Structural Stability}

In order to explore the effects of $\mathrm{V}$ doping on the mechanical properties and electronic structure of $\mathrm{WCoB}$ and $\mathrm{W}_{2} \mathrm{CoB}_{2}$, we first examine the stability of a lattice with different $\mathrm{V}$ doping contents. To reveal the stability, the cohesive energy $\left(\mathrm{E}_{\mathrm{coh}}\right)$ has been calculated, which is defined as follows:

$$
\mathrm{E}_{\mathrm{coh}}=\left(\mathrm{E}_{\text {total }}-\mathrm{aE}_{\mathrm{w}}-\mathrm{bE}_{\mathrm{Co}}-\mathrm{cE}_{\mathrm{B}}-\mathrm{dE}_{\mathrm{V}}\right) /(\mathrm{a}+\mathrm{b}+\mathrm{c}+\mathrm{d})
$$

where $E_{\text {coh }}$ is the cohesive energy of $\mathrm{V}$ doped $\mathrm{WCoB}$ and $\mathrm{W}_{2} \mathrm{CoB}_{2} ; \mathrm{E}_{\text {total }}$ is the total energy of $\mathrm{V}$ doped $\mathrm{WCoB} / \mathrm{W}_{2} \mathrm{CoB}_{2} ; \mathrm{E}_{\mathrm{W}}, \mathrm{E}_{\mathrm{Co}}, \mathrm{E}_{\mathrm{B}}$ and $\mathrm{E}_{\mathrm{V}}$ are the energy of an isolated atoms; $\mathrm{a}, \mathrm{b}, \mathrm{c}$ and $\mathrm{d}$ are the numbers of $\mathrm{W}, \mathrm{Co}, \mathrm{B}, \mathrm{V}$ atoms in the $\mathrm{WCoB}$ or $\mathrm{W}_{2} \mathrm{CoB}_{2}$ lattice, respectively.

The impurity formation energy $\left(\mathrm{E}_{\mathrm{f}}\right)$ can be used to evaluate the change of stability before and after doping, which is given as follows:

$$
\mathrm{E}_{\mathrm{f}}=\mathrm{E}_{\text {total }}-\mathrm{E}_{\mathrm{WCoB} / \mathrm{W}_{2} \mathrm{CoB}_{2}}+\mathrm{xE}_{\mathrm{Co}}-\mathrm{xE}_{\mathrm{V}}
$$




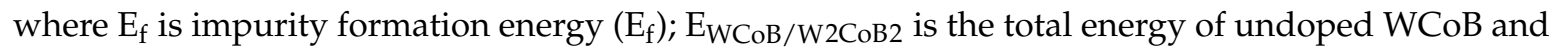
$\mathrm{W}_{2} \mathrm{CoB}_{2} ; \mathrm{x}$ is the number of $\mathrm{V}$ replacing $\mathrm{Co}$ atoms in different $\mathrm{V}$ doped $\mathrm{WCoB}$ and $\mathrm{W}_{2} \mathrm{CoB}_{2}$.

The formation enthalpy is the criterion to estimate the difficulty of formation of $\mathrm{V}$ doped $\mathrm{WCoB} / \mathrm{W}_{2} \mathrm{CoB}_{2}$ from a simple substance, which is shown as follows:

$$
\Delta \mathrm{H}=\mathrm{E}_{\mathrm{coh}}(\mathrm{cell})-\mathrm{aE} \mathrm{E}_{\mathrm{coh}}(\mathrm{W})-\mathrm{bE}_{\mathrm{coh}}(\mathrm{Co})-\mathrm{cE}_{\mathrm{coh}}(\mathrm{B})-\mathrm{dE}_{\mathrm{coh}}(\mathrm{V})
$$

where $\Delta \mathrm{H}$ is the formation enthalpy; $\mathrm{E}_{\mathrm{coh}}$ (cell) is the cohesive energy of $\mathrm{V}$ doped $\mathrm{WCoB} / \mathrm{W}_{2} \mathrm{CoB}_{2}$; $\mathrm{E}_{\mathrm{coh}}(\mathrm{W}), \mathrm{E}_{\mathrm{coh}}(\mathrm{Co}), \mathrm{E}_{\mathrm{coh}}(\mathrm{B})$ and $\mathrm{E}_{\mathrm{coh}}(\mathrm{V})$ are the cohesive energy of $\mathrm{W}, \mathrm{Co}, \mathrm{B}$ and $\mathrm{V}$ in simple substance W (IM3M), Co (P64MMC), B (P4N2) and V (IM3M).

The calculated values of lattice parameters, unit-cell volumes, cohesive energy, impurity formation energy and formation enthalpy of $\mathrm{V}$ doped $\mathrm{WCoB}$ and $\mathrm{W}_{2} \mathrm{CoB}_{2}$ are listed in Table 1, with the experimental data for comparison. The crystal structure of $\mathrm{V}$ doped $\mathrm{WCoB}$ and $\mathrm{W}_{2} \mathrm{CoB}_{2}$ was studied by replacing $\mathrm{Co}$ atoms with different numbers of $\mathrm{V}$ atoms, and the calculated results are consistent with the experimental data, which proves the stability of the present calculations.

Table 1. Calculated results of lattice parameters, cohesive energy $\mathrm{E}_{\mathrm{coh}}(\mathrm{eV} /$ atom), impurity formation energy $\mathrm{E}_{\mathrm{f}}\left(\mathrm{eV} /\right.$ atom), and formation enthalpy $\Delta \mathrm{H}$ of $\mathrm{W}_{4} \mathrm{Co}_{4-} \mathrm{V}_{x} \mathrm{~B}_{4}$ and $\mathrm{W}_{8} \mathrm{Co}_{4-x} \mathrm{~V}_{x} \mathrm{~B}_{8}$.

\begin{tabular}{|c|c|c|c|c|c|}
\hline $\mathrm{WCoB} / \mathrm{W}_{2} \mathrm{CoB}_{2}$ & Lattice Constants (§̊) & $V\left(\AA^{3}\right)$ & $\mathrm{E}_{\mathrm{coh}}$ & $E_{f}$ & $\Delta H$ \\
\hline $\mathrm{W}_{4} \mathrm{Co}_{4} \mathrm{~B}_{4}$-ex & $a=5.746, b=3.203, c=6.652$ & 122.43 & - & - & - \\
\hline $\mathrm{a}-\mathrm{W}_{4} \mathrm{Co}_{4} \mathrm{~B}_{4}$ & $\mathrm{a}=5.745, \mathrm{~b}=3.256, \mathrm{c}=6.624$ & 123.880 & -9.311 & 0 & -0.494 \\
\hline $\mathrm{B}-\mathrm{W}_{4} \mathrm{Co}_{3} \mathrm{VB}_{4}$ & $\mathrm{a}=5.830, \mathrm{~b}=3.210, \mathrm{c}=6.798$ & 127.213 & -9.299 & 0.149 & -0.460 \\
\hline $\mathrm{c}-\mathrm{W}_{4} \mathrm{Co}_{2} \mathrm{~V}_{2} \mathrm{~B}_{4}$-sy & $\mathrm{a}=5.973, \mathrm{~b}=3.162, \mathrm{c}=7.010$ & 130.178 & -9.342 & -0.370 & -0.481 \\
\hline $\mathrm{c}-\mathrm{W}_{4} \mathrm{Co}_{2} \mathrm{~V}_{2} \mathrm{~B}_{4}$-unsy & $\mathrm{a}=5.919, \mathrm{~b}=3.162, \mathrm{c}=6.974$ & 130.437 & -9.321 & -0.122 & -0.460 \\
\hline $\mathrm{d}-\mathrm{W}_{4} \mathrm{CoV}_{3} \mathrm{~B}_{4}$ & $\mathrm{a}=5.937, \mathrm{~b}=3.137, \mathrm{c}=7.165$ & 133.475 & -9.367 & -0.673 & -0.484 \\
\hline $\mathrm{e}-\mathrm{W}_{4} \mathrm{~V}_{4} \mathrm{~B}_{4}$ & $\mathrm{a}=5.953, \mathrm{~b}=3.113, \mathrm{c}=7.345$ & 136.118 & -9.448 & -1.644 & -0.543 \\
\hline $\mathrm{W}_{4} \mathrm{Co}_{2} \mathrm{~B}_{4}$-ex & $\mathrm{a}=7.075, \mathrm{~b}=4.564, \mathrm{c}=3.177$ & 102.59 & - & - & - \\
\hline $\mathrm{f}-\mathrm{W}_{8} \mathrm{Co}_{4} \mathrm{~B}_{8}$ & $\mathrm{a}=7.106, \mathrm{~b}=4.565, \mathrm{c}=3.189$ & 103.454 & -9.486 & 0 & -0.531 \\
\hline $\mathrm{g}-\mathrm{W}_{8} \mathrm{Co}_{3} \mathrm{VB}_{8}$ & $\mathrm{a}=7.182, \mathrm{~b}=4.643, \mathrm{c}=3.156$ & 105.260 & -9.462 & 0.467 & -0.492 \\
\hline $\mathrm{h}-\mathrm{W}_{8} \mathrm{Co}_{2} \mathrm{~V}_{2} \mathrm{~B}_{8}$ & $\mathrm{a}=7.175, \mathrm{~b}=4.670, \mathrm{c}=3.166$ & 106.750 & -9.469 & 0.332 & -0.483 \\
\hline $\mathrm{i}-\mathrm{W}_{8} \mathrm{CoV}_{3} \mathrm{~B}_{8}$ & $\mathrm{a}=7.212, \mathrm{~b}=4.794, \mathrm{c}=3.140$ & 108.566 & -9.472 & 0.274 & -0.470 \\
\hline $\mathrm{j}-\mathrm{W}_{8} \mathrm{~V}_{4} \mathrm{~B}_{8}$ & $\mathrm{a}=7.189, \mathrm{~b}=4.860, \mathrm{c}=3.151$ & 110.094 & -9.505 & -0.386 & -0.487 \\
\hline
\end{tabular}

The lattice parameters and the volume of the unit cell show that $V$ doping leads to a change of lattice parameters and an increase in volume. The atom radius of $\mathrm{V}(\mathrm{r}=171 \mathrm{pm})$ is larger than the atom radius of $\mathrm{Co}(\mathrm{r}=152 \mathrm{pm})$. The difference of the radius is less than $15 \%$, which is in accordance with the criterion of doping. The volume changes of $\mathrm{V}$ doped $\mathrm{WCoB}$ are (b) $2.69 \%$, (c-sy) $5.09 \%$, (c-unsy) $5.29 \%$, (d) $7.75 \%$ and (e) $9.88 \%$, respectively. The volume changes of $\mathrm{V}$ doped $\mathrm{W}_{2} \mathrm{CoB}_{2}$ are (g) $1.75 \%$, (h) $3.19 \%$, (i) $4.94 \%$ and (j) $6.42 \%$, respectively and the similar variation trend can be found in the change of the lattice parameters.

Equation (1) requires negative values of $E_{c o h}$, which refers to a thermodynamically stable structure. With an increase of $\mathrm{V}$ doping content, the cohesive energy of WCoB decreases slightly except $\mathrm{W}_{4} \mathrm{Co}_{3} \mathrm{VB}_{4}$, which indicates that $\mathrm{V}$ doping leads to the increment of stability. For $\mathrm{V}$ doped $\mathrm{W}_{2} \mathrm{CoB}_{2}$, a higher $\mathrm{V}$ doping content contributes to the increment of cohesive energy except $\mathrm{W}_{8} \mathrm{~V}_{4} \mathrm{~B}_{8}$, but all the cohesive energy is less than zero, which indicates that $V$ doping decreases stability.

Impurity formation energy is calculated for $\mathrm{V}$ doped $\mathrm{WCoB}$ and $\mathrm{W}_{2} \mathrm{CoB}_{2}$, which can examine the stability of the doped structure, comparing undoped $\mathrm{WCoB}$ and $\mathrm{W}_{2} \mathrm{CoB}_{2}$. The positive number of impurity formation energy means that $\mathrm{V}$ doping leads to the decrement of the stability, and the negative number means that $\mathrm{V}$ doping leads to the increment of the stability. It is obvious that the $\mathrm{V}$ doping leads to a thermodynamically stable state except $\mathrm{W}_{4} \mathrm{Co}_{3} \mathrm{VB}_{4}$, but $\mathrm{V}$ doped $\mathrm{W}_{2} \mathrm{CoB}_{2}$ are more unstable than $\mathrm{W}_{2} \mathrm{CoB}_{2}$ except $\mathrm{W}_{8} \mathrm{~V}_{4} \mathrm{~B}_{8}$, and these results are consistent with the analysis of cohesive energy. 
Formation enthalpy can be used as the standard of difficulty in a simple substance transforming into compounds. All the values of formation enthalpy are negative, and the increment of formation enthalpy indicates that $\mathrm{V}$ doping leads to the increasing of difficulty of transformation from simple substance to $\mathrm{WCoB}$ structure. However, when the $\mathrm{V}$ doping content reaches the maximum value, the formation enthalpy decreases slightly, which indicates a new stable structure $\mathrm{W}_{4} \mathrm{~V}_{4} \mathrm{~B}_{4}$ and $\mathrm{W}_{8} \mathrm{~V}_{4} \mathrm{~B}_{8}$ is more easily to form. However, the first-principle calculation is calculated in $0 \mathrm{~K}$ and $0 \mathrm{GPa}$, which needs further study on the thermodynamic formation process.

Overall, it can be concluded that all $\mathrm{V}$ doped structures retain a stable state. The unsymmetrical structure $\mathrm{W}_{4} \mathrm{Co}_{2} \mathrm{~V}_{2} \mathrm{~B}_{4}$ is more unstable than the symmetrical structure $\mathrm{W}_{4} \mathrm{Co}_{2} \mathrm{~V}_{2} \mathrm{~B}_{4}$, which will not be considered in the next section.

\subsection{Mechanical Properties}

The mechanical properties of different contents of $\mathrm{V}$ doped $\mathrm{WCoB}$ and $\mathrm{W}_{2} \mathrm{CoB}_{2}$, including the elastic constants, bulk modulus, elastic modulus, shear modulus, B/G ratio, Poisson's ratio, and anisotropic index, are shown in Tables 2 and 3 and Figure 2. The traditional mechanical stability conditions should be taken into consideration before the analysis of mechanical properties. For orthorhombic crystals $\mathrm{WCoB}$ and $\mathrm{W}_{2} \mathrm{CoB}_{2}$, there are nine independent elastic stiffness constants, and the standards can be expressed as follows:

$$
\begin{gathered}
\mathrm{c}_{\mathrm{ii}}>0,\left[\mathrm{c}_{11}+\mathrm{c}_{22}+\mathrm{c}_{33}+2\left[\mathrm{c}_{12}+\mathrm{c}_{13}+\mathrm{c}_{23}\right]\right]>0,\left(\mathrm{c}_{11}+\mathrm{c}_{22}-2 \mathrm{c}_{12}\right)>0, \\
\left(\mathrm{c}_{11}+\mathrm{c}_{33}-2 \mathrm{c}_{13}\right)>0,\left(\mathrm{c}_{22}+\mathrm{c}_{33}-2 \mathrm{c}_{23}\right)>0
\end{gathered}
$$

where $C_{i j}$ is the single crystal elastic constant. It is obvious that all structures satisfy the stability standards. The mechanical properties of different structures are characterized by the set of elastic constants. For orthorhombic structures $\mathrm{WCoB}$ and $\mathrm{W}_{2} \mathrm{CoB}_{2}, \mathrm{~B}_{\mathrm{V}}, \mathrm{B}_{\mathrm{R}}, \mathrm{G}_{\mathrm{V}}$, and $\mathrm{G}_{\mathrm{R}}$ can be expressed by using the following equations:

$$
\begin{gathered}
\mathrm{B}_{\mathrm{R}}=1 /\left[\left(\mathrm{S}_{11}+\mathrm{S}_{22}+\mathrm{S}_{33}\right)+2\left(\mathrm{~S}_{12}+\mathrm{S}_{13}+\mathrm{S}_{23}\right)\right] \\
\mathrm{B}_{\mathrm{V}}=\left(\mathrm{C}_{11}+\mathrm{C}_{22}+\mathrm{C}_{33}\right) / 9+2\left(\mathrm{C}_{12}+\mathrm{C}_{13}+\mathrm{C}_{23}\right) / 9 \\
\mathrm{G}_{\mathrm{R}}=15 /\left[4\left(\mathrm{~S}_{11}+\mathrm{S}_{22}+\mathrm{S}_{33}\right)-4\left(\mathrm{~S}_{12}+\mathrm{S}_{13}+\mathrm{S}_{23}\right)+3\left(\mathrm{~S}_{44}+\mathrm{S}_{55}+\mathrm{S}_{66}\right)\right] \\
\mathrm{B}_{\mathrm{V}}=\left(\mathrm{C}_{11}+\mathrm{C}_{22}+\mathrm{C}_{33}\right) / 15-\left(\mathrm{C}_{12}-\mathrm{C}_{13}-\mathrm{C}_{23}\right) / 15+\left(\mathrm{C}_{44}+\mathrm{C}_{55}+\mathrm{C}_{66}\right) / 5
\end{gathered}
$$

where $S_{i j}$ is the elastic compliant coefficient, which can be converted from the corresponding $C_{i j}$ matrix equation. Bulk modulus B and shear modulus $G$ are calculated by Voigt-Reuss-Hill approximations [43], which are shown in Equations (9) and (10). According to the structural symmetry, Young's modulus E and Poisson's ratio $v$ can also be calculated by Equations (11) and (12):

$$
\begin{gathered}
\mathrm{B}=\left(\mathrm{B}_{V}+\mathrm{B}_{\mathrm{R}}\right) / 2 \\
\mathrm{G}=\left(\mathrm{G}_{V}+\mathrm{G}_{\mathrm{R}}\right) / 2 \\
\mathrm{E}=(9 \mathrm{BG}) /(3 \mathrm{~B}+\mathrm{G}) \\
v=(3 \mathrm{~B}-2 \mathrm{G}) /[2[3 \mathrm{~B}+\mathrm{G}]]
\end{gathered}
$$

A universal elastic anisotropy index $\left(\mathrm{A}^{\mathrm{U}}\right)$ can also be calculated as follows, which are used to account for the shear and bulk contributions.

$$
\mathrm{A}^{\mathrm{U}}=5 \mathrm{G}_{\mathrm{V}} / \mathrm{G}_{\mathrm{R}}+\mathrm{B}_{\mathrm{V}} / \mathrm{B}_{\mathrm{R}}-6 \geq 0
$$


The elastic constants of $\mathrm{V}$ doped $\mathrm{WCoB}$ and $\mathrm{W}_{2} \mathrm{CoB}_{2}$ are shown in Tables 2 and 3, which satisfy the Born stability criteria for orthorhombic crystals [44,45]. For orthorhombic WCoB ternary boride, it is obvious that $\mathrm{C}_{11}, \mathrm{C}_{22}, \mathrm{C}_{33}$ decrease with the increasing of $\mathrm{V}$ doping content, indicating that $\mathrm{V}$ doping contributes to the decreasing of deformation resistance along $a, b, c$ axes. Almost all the $C_{11}$ are higher than $C_{33}$, which demonstrates that the deformation resistance along the a axis is stronger than that along the $\mathrm{c}$ axis, which is attributed to the stronger $\mathrm{B}-\mathrm{Co}$ bonds. For orthorhombic $\mathrm{W}_{2} \mathrm{CoB}_{2}$ ternary boride, $C_{22}$ is larger than $C_{11}$ and $C_{33}$, implying that $b$ axis has the largest stiffness. Although all elastic constants decrease with the increase of $\mathrm{V}$ doping content, $\mathrm{C}_{66}$ has the biggest decreasing amplitude among all elastic constants. The phenomenon shows that the stiffness obviously decreases along the $\mathrm{XZ}$ direction, which is attributed to the bigger atom radius of $\mathrm{V}$ and the weaker bonds of $\mathrm{W}-\mathrm{V}$ metallic bonds.

Table 2. The calculated elastic constants (in GPa) of $\mathrm{W}_{4} \mathrm{Co}_{4-x} \mathrm{~V}_{x} \mathrm{~B}_{4}$.

\begin{tabular}{cccccc}
\hline & $\mathbf{a}-\mathbf{W}_{\mathbf{4}} \mathbf{C o}_{\mathbf{4}} \mathbf{B}_{\mathbf{4}}$ & $\mathbf{B}-\mathbf{W}_{\mathbf{4}} \mathbf{C o}_{\mathbf{3}} \mathbf{V B}_{\mathbf{4}}$ & $\mathbf{c}-\mathbf{W}_{\mathbf{4}} \mathbf{C o}_{\mathbf{2}} \mathbf{V}_{\mathbf{2}} \mathbf{B}_{\mathbf{4}}$ & $\mathbf{d}-\mathbf{W}_{\mathbf{4}} \mathbf{C o V}_{\mathbf{3}} \mathbf{B}_{\mathbf{4}}$ & e- $\mathbf{W}_{\mathbf{4}} \mathbf{V}_{\mathbf{4}} \mathbf{B}_{\mathbf{4}}$ \\
\hline $\mathrm{C}_{11}$ & 551.84 & 493.02 & 524.73 & 515.56 & 556.79 \\
$\mathrm{C}_{22}$ & 515.90 & 475.98 & 484.01 & 487.05 & 497.32 \\
$\mathrm{C}_{33}$ & 609.34 & 558.45 & 549.28 & 514.86 & 522.41 \\
$\mathrm{C}_{44}$ & 234.37 & 216.15 & 219.46 & 210.78 & 220.10 \\
$\mathrm{C}_{55}$ & 190.14 & 169.89 & 165.62 & 141.02 & 149.42 \\
$\mathrm{C}_{66}$ & 236.81 & 221.97 & 237.74 & 212.29 & 228.58 \\
$\mathrm{C}_{12}$ & 264.24 & 270.44 & 242.05 & 229.14 & 206.52 \\
$\mathrm{C}_{13}$ & 177.11 & 180.14 & 161.29 & 154.40 & 127.24 \\
$\mathrm{C}_{23}$ & 225.26 & 220.23 & 206.40 & 190.04 & 177.06 \\
\hline
\end{tabular}

Table 3. The calculated elastic constants (in GPa) of $\mathrm{W}_{8} \mathrm{Co}_{4-x} \mathrm{~V}_{x} \mathrm{~B}_{8}$.

\begin{tabular}{cccccc}
\hline & $\mathbf{a}-\mathbf{W}_{\mathbf{4}} \mathbf{C o}_{\mathbf{4}} \mathbf{B}_{\mathbf{4}}$ & $\mathbf{B}-\mathbf{W}_{\mathbf{4}} \mathbf{C o}_{\mathbf{3}} \mathbf{V B}_{\mathbf{4}}$ & $\mathbf{c}-\mathbf{W}_{\mathbf{4}} \mathbf{C o}_{\mathbf{2}} \mathbf{V}_{\mathbf{2}} \mathbf{B}_{\mathbf{4}}$ & $\mathbf{d}-\mathbf{W}_{\mathbf{4}} \mathrm{CoV}_{\mathbf{3}} \mathbf{B}_{\mathbf{4}}$ & e- $\mathbf{W}_{\mathbf{4}} \mathbf{V}_{\mathbf{4}} \mathbf{B}_{\mathbf{4}}$ \\
\hline $\mathrm{C}_{11}$ & 589.86 & 544.95 & 538.71 & 517.45 & 545.80 \\
$\mathrm{C}_{22}$ & 608.81 & 561.13 & 564.37 & 565.08 & 586.25 \\
$\mathrm{C}_{33}$ & 542.51 & 490.30 & 482.64 & 482.50 & 499.95 \\
$\mathrm{C}_{44}$ & 241.93 & 241.06 & 239.58 & 244.70 & 257.87 \\
$\mathrm{C}_{55}$ & 245.71 & 228.43 & 227.96 & 244.34 & 235.65 \\
$\mathrm{C}_{66}$ & 210.82 & 95.46 & 76.37 & 63.87 & 37.31 \\
$\mathrm{C}_{12}$ & 162.49 & 158.43 & 156.86 & 156.72 & 133.52 \\
$\mathrm{C}_{13}$ & 250.69 & 261.84 & 258.16 & 258.26 & 238.41 \\
$\mathrm{C}_{23}$ & 238.90 & 248.74 & 232.46 & 212.01 & 195.72 \\
\hline
\end{tabular}

According to the elastic constants, the calculated values of shear modulus $G$, bulk modulus $B$, Young's modulus E, Poisson's ratio $\gamma, \mathrm{B} / \mathrm{G}$ ratio and universal anisotropic index $\left(\mathrm{A}^{\mathrm{U}}\right)$ of $\mathrm{Cr}, \mathrm{Mn}, \mathrm{V}$ $\mathrm{WCoB}$ and $\mathrm{W}_{2} \mathrm{CoB}_{2}$ are shown in Figure 2. It is an obvious bulk modulus of $\mathrm{WCoB}$ and $\mathrm{W}_{2} \mathrm{CoB}_{2}$ decreases slightly with the increase of the $\mathrm{V}$ doping contents, implying that $\mathrm{V}$ doping leads to the increase of stress concentration and the decrease of deformation resistance. The calculated values of shear modulus and elastic modulus show a similar trend with variations of the $\mathrm{V}$ doping content. For orthorhombic $\mathrm{WCoB}, \mathrm{V}$ doping leads to the decrease of shear modulus and elastic modulus, and symmetrical structures have higher values. $V$ doping leads to the sharp decrement of shear modulus and elastic modulus for $\mathrm{W}_{2} \mathrm{CoB}_{2}$ ternary boride. 

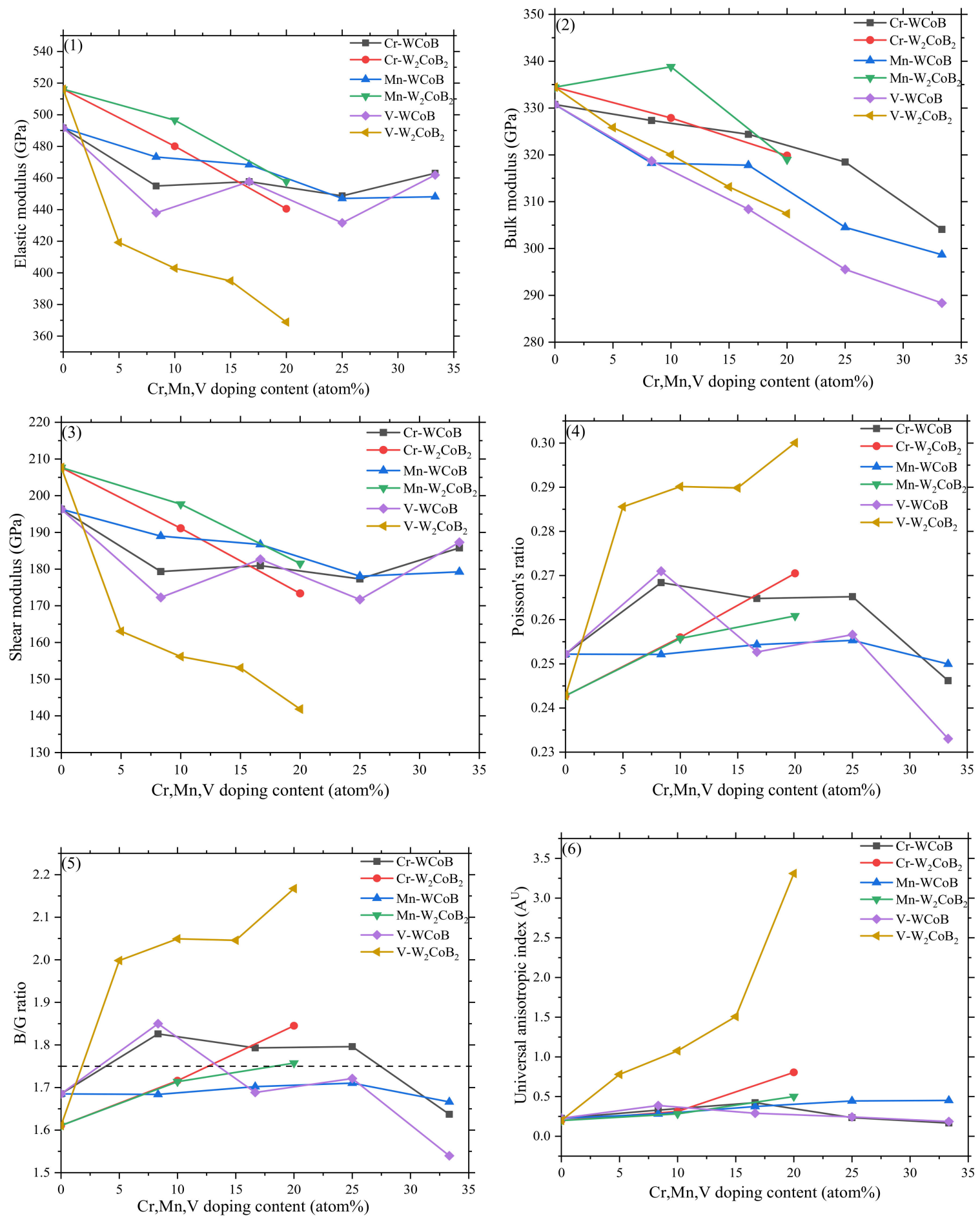

Figure 2. Calculated values of (1) Elastic modulus E (GPa); (2) Bulk modulus B (GPa); (3) Shear modulus G (GPa); (4) Poisson's ratio $\gamma$; (5) B/G ratio; and (6) universal anisotropic index $\left(\mathrm{A}^{\mathrm{U}}\right)$ of $\mathrm{W}_{4} \mathrm{Co}_{4-x}(\mathrm{Cr}, \mathrm{Mn}, \mathrm{V})_{x} \mathrm{~B}_{4}$ and $\mathrm{W}_{8} \mathrm{Co}_{4-x}(\mathrm{Cr}, \mathrm{Mn}, \mathrm{V})_{x} \mathrm{~B}_{8}(x=0,1,2,3,4)$.

The brittleness can be evaluated by Poisson's ratio [46]. Poisson's ratio fluctuates around 0.25 and decreases slightly for $\mathrm{WCoB}$ ternary boride, which means $\mathrm{V}$ doping contributes to a decrease in ductility. $V$ doping contributes to the obvious increment of Poisson's ratio of $\mathrm{W}_{2} \mathrm{CoB}_{2}$, implying that $\mathrm{V}$ doping leads to an increase of ductility. Generally speaking, the 1.75 ratio of $B / G$ is the criterion with which evaluate the ductility of materials [47]. If $\mathrm{B} / \mathrm{G}$ is less than 1.75 , a material can be determined a brittle material, and with values higher than 1.75 it can be considered a ductile material. So, the B/G 
ratio is in consistent with the analysis of Poisson's ratio. $V$ doping leads to the slight decrement of ductility of $\mathrm{WCoB}$ ternary boride and the obvious increment in $\mathrm{W}_{2} \mathrm{CoB}_{2}$ ternary boride. The results indicate that $\mathrm{V}$ doping leads to an increase of metallicity. A universal elastic anisotropy index $\left(\mathrm{A}^{\mathrm{U}}\right)$ is the criterion with which to evaluate the anisotropy. Because the departure of $\mathrm{A}^{\mathrm{U}}$ from 0 means an increase of anisotropy, it is obvious that $\mathrm{V}$ doping leads to the increment of anisotropy for $\mathrm{W}_{2} \mathrm{CoB}_{2}$ ternary boride. However, the variation of $\mathrm{A}^{\mathrm{U}}$ of $\mathrm{WCoB}$ is minor, which indicates that the effect of $\mathrm{V}$ doping is more obvious on the supercell of $\mathrm{W}_{2} \mathrm{CoB}_{2}$.

Based on our previous work $[35,36]$, the different contents of $\mathrm{Cr}$, Mn doped $\mathrm{WCoB}$ and $\mathrm{W}_{2} \mathrm{CoB}_{2}$ have been studied by first-principle calculation. Compared with the previous data, it is obvious that the low content of $\mathrm{Cr}, \mathrm{Mn}, \mathrm{V}$ doping shows relatively higher mechanical properties, especially on the bulk modulus and the $B / G$ ratio. Ductility is one of the most important properties, and the low content of $\mathrm{Cr}, \mathrm{V}$ doped $\mathrm{WCoB}$ shows the best ductility except for $\mathrm{V}$ doped $\mathrm{W}_{2} \mathrm{CoB}_{2}$. Although $\mathrm{V}$ doped $\mathrm{W}_{2} \mathrm{CoB}_{2}$ shows the best ductility, the decrement of mechanical properties limits its application.

\subsection{Population Analysis and Hardness}

The chemistry bond plays a crucial role in the mechanical properties, especially on the hardness of the hard phase. The bonding strength among atoms shows information about hardness and is determined by the overlap population [48]. The covalent bonds have a larger overlap population than ionic bonds, which are bigger than zero. Anti-bonding exists when the overlap population is less than zero. The properties of chemical bonds can be analyzed by the average overlap population, which is provided by Zhou [49], and the equation is as follows:

$$
\mathrm{n}_{\mathrm{AB}}=\frac{\sum_{\mathrm{i}} \mathrm{n}_{\mathrm{i}}^{\mathrm{AB}} \mathrm{N}_{\mathrm{i}}}{\sum_{\mathrm{i}} \mathrm{N}_{\mathrm{i}}}
$$

where $N_{i}$ is the total number of $A-B$ bonds and $n_{i}^{A B}$ is the bond population of $A-B$ bond of the $i$ type.

The calculated results of the average overlap population of different bonds in $\mathrm{WCoB}$ and $\mathrm{W}_{2} \mathrm{CoB}_{2}$ ternary boride is listed in Tables 4 and 5 . For WCoB ternary boride, $\mathrm{V}$ doping leads to an increase of average overlap population, implying $\mathrm{V}$ doping contributes to the increasing of covalent properties for most bonds. Compared with $\mathrm{W}_{2} \mathrm{CoB}_{2}$ ternary boride, there are no existing $\mathrm{B}-\mathrm{B}$ bonds in the $\mathrm{V}$ doped WCoB ternary boride, which is attributed to the long distance between $\mathrm{B}$ atoms. The negative average overlap population means the repulsion force among atoms, and all the negative value appears between metal atoms. Similarly, average overlap population increases with the increase of $\mathrm{V}$ doping content in $\mathrm{W}_{2} \mathrm{CoB}_{2}$ ternary boride. It is clear that $\mathrm{V}$ doping contributes to the increase of covalent properties for most bonds. However, the population of $\mathrm{B}-\mathrm{V}$ and $\mathrm{Co}-\mathrm{V}$ bonds is less than $\mathrm{B}-\mathrm{Co}$ and $\mathrm{Co}-\mathrm{Co}$ bonds, so the $\mathrm{V}$ doping leads to a decrease of covalent properties for the WCoB and $\mathrm{W}_{2} \mathrm{CoB}_{2}$ structure.

Table 4. Calculated overlap population of bonds for $\mathrm{W}_{4} \mathrm{Co}_{4-x} \mathrm{~V}_{x} \mathrm{~B}_{4}$.

\begin{tabular}{|c|c|c|c|c|c|}
\hline & $a-W_{4} C_{0} B_{4}$ & $\mathrm{~B}-\mathrm{W}_{4} \mathrm{Co}_{3} \mathrm{VB}_{4}$ & $c-W_{4} \mathrm{Co}_{2} \mathrm{~V}_{2} \mathrm{~B}_{4}$ & $\mathrm{~d}-\mathrm{W}_{4} \mathrm{CoV}_{3} \mathrm{~B}_{4}$ & e- $W_{4} V_{4} B_{4}$ \\
\hline B-B & - & - & - & - & - \\
\hline $\mathrm{B}-\mathrm{Co}$ & 0.307 & 0.309 & 0.303 & 0.300 & - \\
\hline $\mathrm{B}-\mathrm{W}$ & 0.530 & 0.558 & 0.565 & 0.592 & 0.603 \\
\hline B-V & - & 0.123 & 0.157 & 0.156 & 0.157 \\
\hline $\mathrm{Co}-\mathrm{Co}$ & -0.150 & -0.140 & -0.0900 & - & - \\
\hline $\mathrm{Co}-\mathrm{W}$ & -0.055 & -0.0100 & -0.0150 & 0.0575 & - \\
\hline $\mathrm{Co}-\mathrm{V}$ & - & -0.330 & - & -0.220 & - \\
\hline $\mathrm{W}-\mathrm{W}$ & -0.055 & -0.055 & 0.0300 & 0.100 & 0.150 \\
\hline $\mathrm{W}-\mathrm{V}$ & - & -0.240 & -0.1125 & -0.0950 & -0.0425 \\
\hline $\mathrm{V}-\mathrm{V}$ & - & - & -0.530 & -0.410 & -0.33 \\
\hline
\end{tabular}


Table 5. Calculated overlap population of bonds for $\mathrm{W}_{8} \mathrm{Co}_{4-x} \mathrm{~V}_{x} \mathrm{~B}_{8}$.

\begin{tabular}{|c|c|c|c|c|c|}
\hline & $a-W_{8} C_{o_{4}} B_{8}$ & $\mathrm{~B}-\mathrm{W}_{8} \mathrm{Co}_{3} \mathrm{VB}_{8}$ & $\mathrm{c}-\mathrm{W}_{8} \mathrm{Co}_{2} \mathrm{~V}_{2} \mathrm{~B}_{8}$ & $d-W_{8} \operatorname{CoV}_{3} B_{8}$ & $e-W_{8} V_{4} B_{8}$ \\
\hline B-B & 0.590 & 0.5925 & 0.575 & 0.568 & 0.580 \\
\hline $\mathrm{B}-\mathrm{Co}$ & 0.210 & 0.237 & 0.27 & 0.29 & - \\
\hline $\mathrm{B}-\mathrm{W}$ & 0.200 & 0.201 & 0.208 & 0.208 & 0.207 \\
\hline B-V & - & 0.13 & 0.14 & 0.187 & 0.220 \\
\hline $\mathrm{Co}-\mathrm{Co}$ & - & - & - & - & - \\
\hline $\mathrm{Co}-\mathrm{W}$ & 0.0833 & 0.0933 & 0.113 & 0.127 & - \\
\hline $\mathrm{Co}-\mathrm{V}$ & - & - & - & - & - \\
\hline$W-W$ & -0.0833 & -0.0492 & 0 & 0.0445 & 0.0267 \\
\hline $\mathrm{W}-\mathrm{V}$ & - & -0.01 & 0.0167 & 0.04 & 0.0867 \\
\hline $\mathrm{V}-\mathrm{V}$ & - & - & - & - & - \\
\hline
\end{tabular}

Hardness is one of the most important properties for hard alloy, and different hardness models are employed to study the influence of $\mathrm{V}$ doping on $\mathrm{WCoB}$ and $\mathrm{W}_{2} \mathrm{CoB}_{2}$ ternary boride. Hardness is a macroscopic property, which is affected by different factors. Some hardness models are based on mechanical properties, and some hardness models are based on population analysis. To explore the hardness of $\mathrm{WCoB}$ and $\mathrm{W}_{2} \mathrm{CoB}_{2}$ ternary boride, the Vickers hardness $\left(\mathrm{H}_{\mathrm{V}}\right)$ is calculated by three hardness models.

Pugh [50] proposed a simple hardness model in 1954, which can be expressed by $\mathrm{H}_{\mathrm{V}}=0.151 \mathrm{G}$. Based on previous models, Chen [51] introduces the Pugh's ratio to evaluate the ductility of materials, which can be expressed as $k=G / B$. The hardness model can be expressed as follows:

$$
\mathrm{H}_{\mathrm{v}}=2\left(\mathrm{k}^{2} \mathrm{G}\right)^{0.585}-3
$$

where $\mathrm{k}$ is the Pugh's ratio and $\mathrm{G}$ is the shear modulus.

As we know, the mechanical properties are the macroscopic properties, and the previous hardness model only shows the statistical relationship between hardness and mechanical properties. Gao [52] established a new hardness model, which is based on population analysis. Gao proposes that the resistance is proportional to the homo-polar energy gap and the bond strength is determined by overlap populations, which can be evaluated by first-principle calculations. The hardness of bonds can be expressed by follow equations:

$$
\begin{gathered}
\mathrm{H}_{\gamma}^{\mu}(\mathrm{GPa})=\operatorname{AP}^{\mu}\left(\gamma_{\mathrm{b}}^{\mu}\right)^{-\frac{5}{3}}, \mathrm{~A}=740 \\
\gamma_{\mathrm{b}}^{\mu}=\left(\mathrm{d}^{\mu}\right)^{3} / \sum_{\mu}\left(\mathrm{d}^{\mu}\right)^{3} \mathrm{~N}_{\mathrm{b}}^{\mu}, \mathrm{N}_{\mathrm{b}}^{\mu}=\mathrm{N}^{\mu} / \Omega
\end{gathered}
$$

where $\mathrm{P}^{\mu}$ is the overlap population of $\mu$-type bond; $\mathrm{H}_{\gamma}^{\mu}$ is the hardness of $\mu$-type bond; $\mathrm{N}_{b}^{\mu}$ is the bond density per cubic angstroms of $\mu$-type bond; $\mathrm{d}^{\mu}$ is the bond length of $\mu$-type bond; $\Omega$ is the cell volume. The hardness of the metallic bond is not considered in this model, because the calculation results of metallic bonds cannot be calculated accurately in the first-principle calculations. The electrons of the metallic bonds are shared in the whole material. The hardness of metallic bonds is not taken into account in the hardness model. The Gao's hardness of materials can be expressed by the geometric average of all bond hardness, which is shown as follows:

$$
\mathrm{H}_{\gamma}^{\mu}(\mathrm{GPa})=\left[\left(\mathrm{H}_{\gamma}^{\mu_{1}}\right)^{\mathrm{m}_{1}}\left(\mathrm{H}_{\gamma}^{\mu_{2}}\right)^{\mathrm{m}_{2}} \ldots\left(\mathrm{H}_{\gamma}^{\mu_{\mathrm{n}}}\right)^{\mathrm{m}_{\mathrm{n}}}\right] \frac{1}{\mathrm{~m}_{1}+\mathrm{m}_{2}+\mathrm{m}_{3}} .
$$

where $m_{n}$ is the bond number of $\mu$-type bond. 
The vickers hardness of $\mathrm{V}$ doped $\mathrm{WCoB}$ and $\mathrm{W}_{2} \mathrm{CoB}_{2}$ is shown in Figure 3, which are named $\mathrm{Hv}$-Chen and Hv-Gao. The hardness models are usually based on the binary oxide, so the hardness is characterized by different models to explore the variation of the hardness of $\mathrm{V}$ doped WCoB and $\mathrm{W}_{2} \mathrm{CoB}_{2}$ ternary boride.
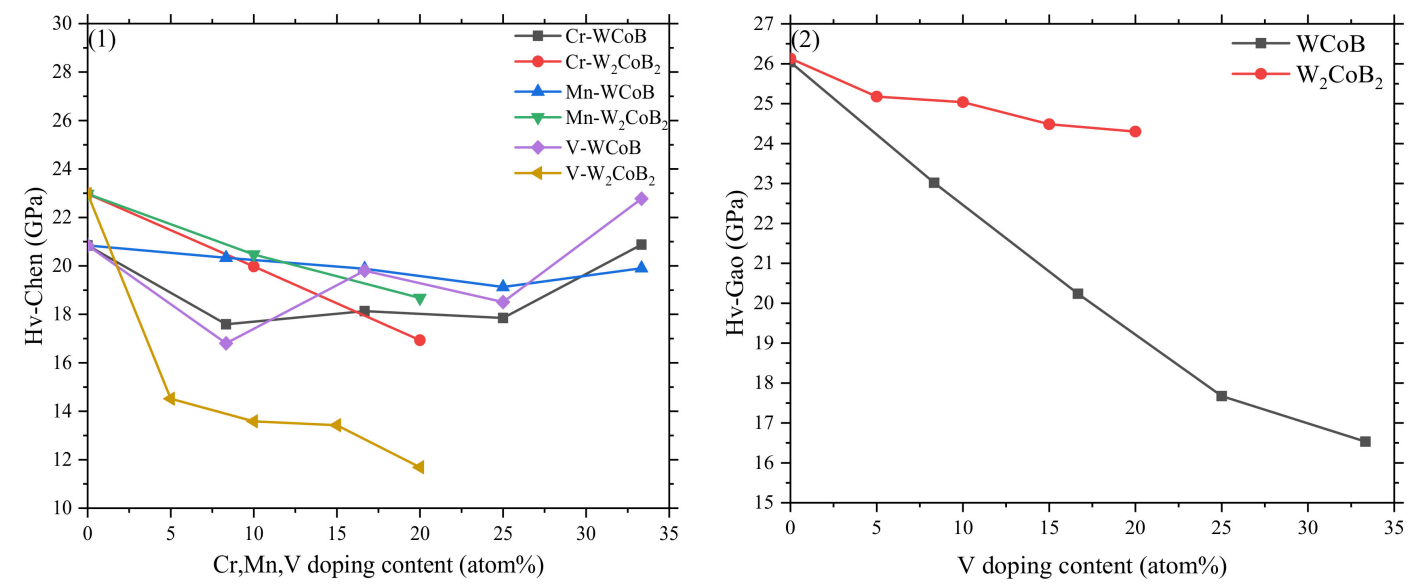

Figure 3. Plots of theoretical hardness versus $\mathrm{V}$ doping content of $\mathrm{W}_{4} \mathrm{Co}_{4-x}(\mathrm{Cr}, \mathrm{Mn}, \mathrm{V})_{x} \mathrm{~B}_{4}$ and $\mathrm{W}_{8} \mathrm{Co}_{4-x} \mathrm{~V}_{x} \mathrm{~B}_{8}(x=0,1,2,3,4)$, obtained by different models: (1) Hv-Chen; (2) Hv-Gao.

For WCoB ternary boride, the hardness varies around the hardness of the undoped structure. However, the mechanical properties have been studied in the previous section, and the bulk modulus decreases with increasing $\mathrm{V}$ doping content. It is obvious that the variation trend of $\mathrm{Hv}$-Chen is similar to the variation trend of the shear modulus, which indicates that the shear modulus plays an important role in the hardness. The symmetrical doped structure has a relatively higher hardness than the unsymmetrical structure, implying better performance of symmetrical structures. However, Gao's model shows that $\mathrm{V}$ doping leads to a decreasing in hardness, which is consistent with population analysis.

For $\mathrm{W}_{2} \mathrm{CoB}_{2}$ ternary boride, it is obvious that all hardness models show that $\mathrm{V}$ doping contributes to the decrement of hardness. It is more likely to be caused by the larger atom radius of $\mathrm{V}(\mathrm{r}=171 \mathrm{pm})$ than by $\mathrm{Co}(\mathrm{r}=152 \mathrm{pm})$, which leads to the weaker $\mathrm{B}-\mathrm{V}$ covalent bonds and $\mathrm{W}-\mathrm{V}$ metallic bonds. The Gao' model especially shows that decreasing amplitude is little in $\mathrm{W}_{2} \mathrm{CoB}_{2}$ ternary boride.

Compared with the effect of $\mathrm{Cr}$ and $\mathrm{Mn}$ doped $\mathrm{WCoB}$ and $\mathrm{W}_{2} \mathrm{CoB}_{2}[35,36]$, we can assume $\mathrm{Cr}$ doped $W C o B$ or $V$ doped $W_{2} \mathrm{CoB}_{2}$ are the valuable choices of the experiment because Gao's model depends on the type of cell, and the previous studies are based on the unit cell of $\mathrm{W}_{2} \mathrm{CoB}_{2}$. So only $\mathrm{Hv}-\mathrm{Gao}$ of $\mathrm{V}$ doped $\mathrm{WCoB}$ and $\mathrm{W}_{2} \mathrm{CoB}_{2}$ is shown in Figure 3. The mechanical properties and Vickers hardness of $\mathrm{Cr}, \mathrm{Mn}, \mathrm{V}$ doped $\mathrm{WCoB}$ and $\mathrm{W}_{2} \mathrm{CoB}_{2}$ indicates $\mathrm{Cr}$ doped $\mathrm{WCoB}$ and $\mathrm{Mn}$ doped $\mathrm{W}_{2} \mathrm{CoB}_{2}$ are the best choice of doping element and ternary boride, which have high ductility, hardness and relatively high mechanical properties.

\subsection{Density of States}

The nature of mechanical properties can be revealed by studying the electronic structure and chemical bonding features. The total density of states (DOS) and partial density of states (PDOS) of V doped $\mathrm{WCoB}$ and $\mathrm{W}_{2} \mathrm{CoB}_{2}$ are illustrated in Figures 4 and 5. The black vertical dashed line represents the Fermi level and the deep valley around the Fermi level is named the pseudogap $\left(\mathrm{E}_{\mathrm{p}}\right)$. The orbitals above the pseudogap are usually composed of $d-d$ orbitals and contribute to the formation of metallic bonds. The larger displacement between the pseudogap is related to the formation of covalent bonds and the weakness of metallic bonds. Yu [53] found a higher value of density of states at Fermi level indicating the increasing stability of non-crystal and quasi-crystal. However, the stability of typical crystals, including WCoB and $\mathrm{W}_{2} \mathrm{CoB}_{2}$, cannot be judged by the value of density of states at Fermi level. 
The calculated DOS and PDOS of V doped WCoB are illustrated in Figure 4. In a range from $-15 \mathrm{eV}$ to $10 \mathrm{eV}$, there are several peaks which can be divided into different peaks. So, we chose some typical peaks to discuss the effect of $\mathrm{V}$ doping on $\mathrm{WCoB}$. We named P1, P2, P3, P4 and P5 for peaks located at $-8.6 \mathrm{eV},-6.0 \mathrm{eV},-1.0 \mathrm{eV}, 0.83 \mathrm{eV}, 1.9 \mathrm{eV}$. Because P1 is composed of B-2s orbital and W-5d orbital and P2 is composed of B-2p orbital and W-5d orbital, it is obvious that P1 and P2 varies little with increasing $\mathrm{V}$ doping content. By viewing Figure $4 \mathrm{a}$, we can see that the location of B-2s orbital and B-2p orbital are away from Fermi level. These peaks change little with increasing $\mathrm{V}$ doping content and mainly form a covalent bond between B-W, B-Co and B-V, which gives a positive contribution to the shear modulus and hardness by enlarging the pseudogap. Because there exists a strong hybridization between B-2p orbital, V-3d orbital, Co-3d orbital and W-5d orbital, some peaks vanish with increasing V doping content.
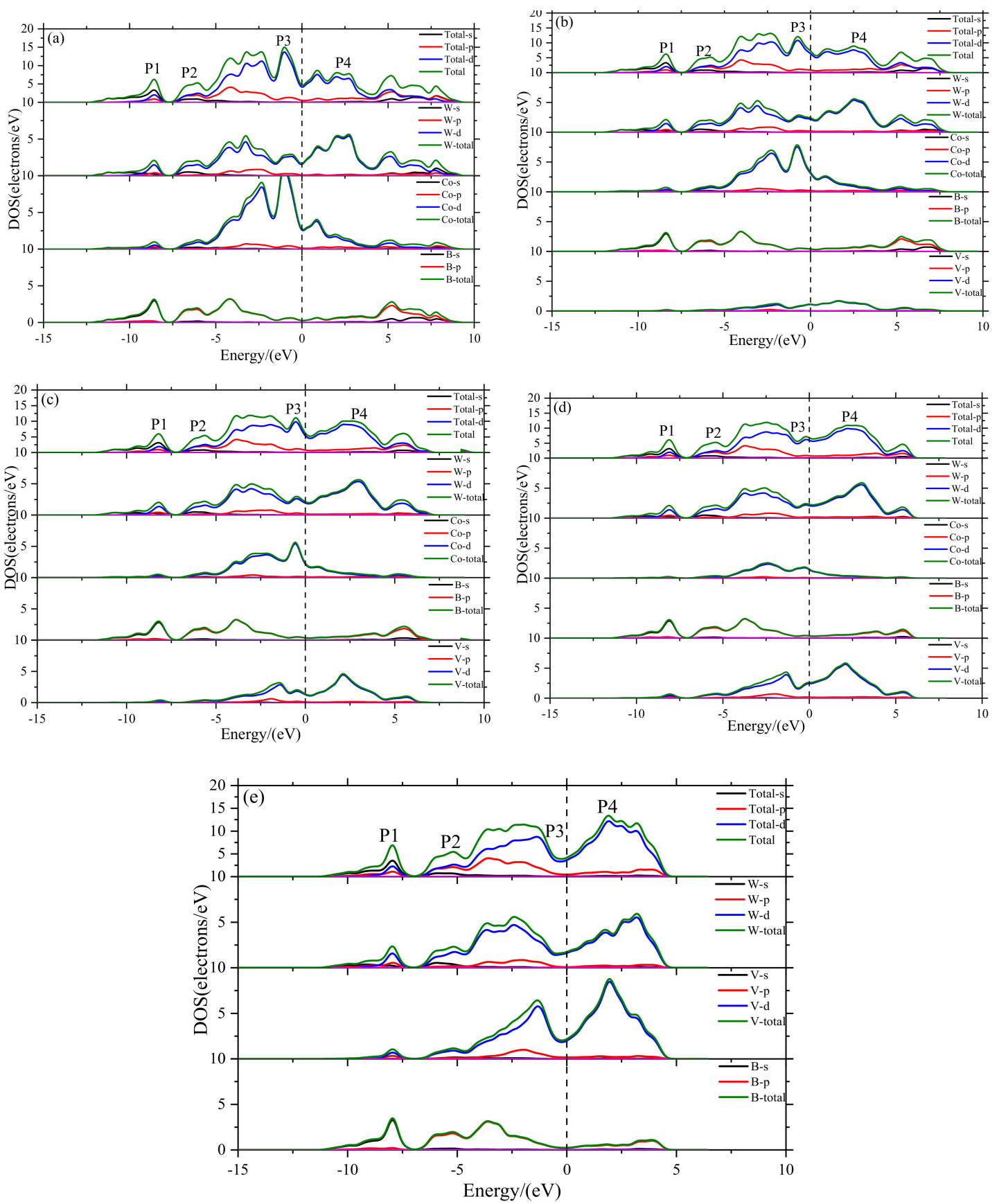

Figure 4. Plots of total and partial density of states of $\mathrm{WCoB}$ with different $\mathrm{Mn}$ doping content ((a) $\mathrm{W}_{4} \mathrm{Co}_{4} \mathrm{~B}_{4} ;$ (b) $\mathrm{W}_{4} \mathrm{Co}_{3} \mathrm{VB}_{4} ;$ (c) $\mathrm{W}_{4} \mathrm{Co}_{2} \mathrm{~V}_{2} \mathrm{~B}_{4} ;$ (d) $\mathrm{W}_{4} \mathrm{CoV}_{3} \mathrm{~B}_{4} ;\left(\right.$ e) $\mathrm{W}_{4} \mathrm{~V}_{4} \mathrm{~B}_{4}$ ). 

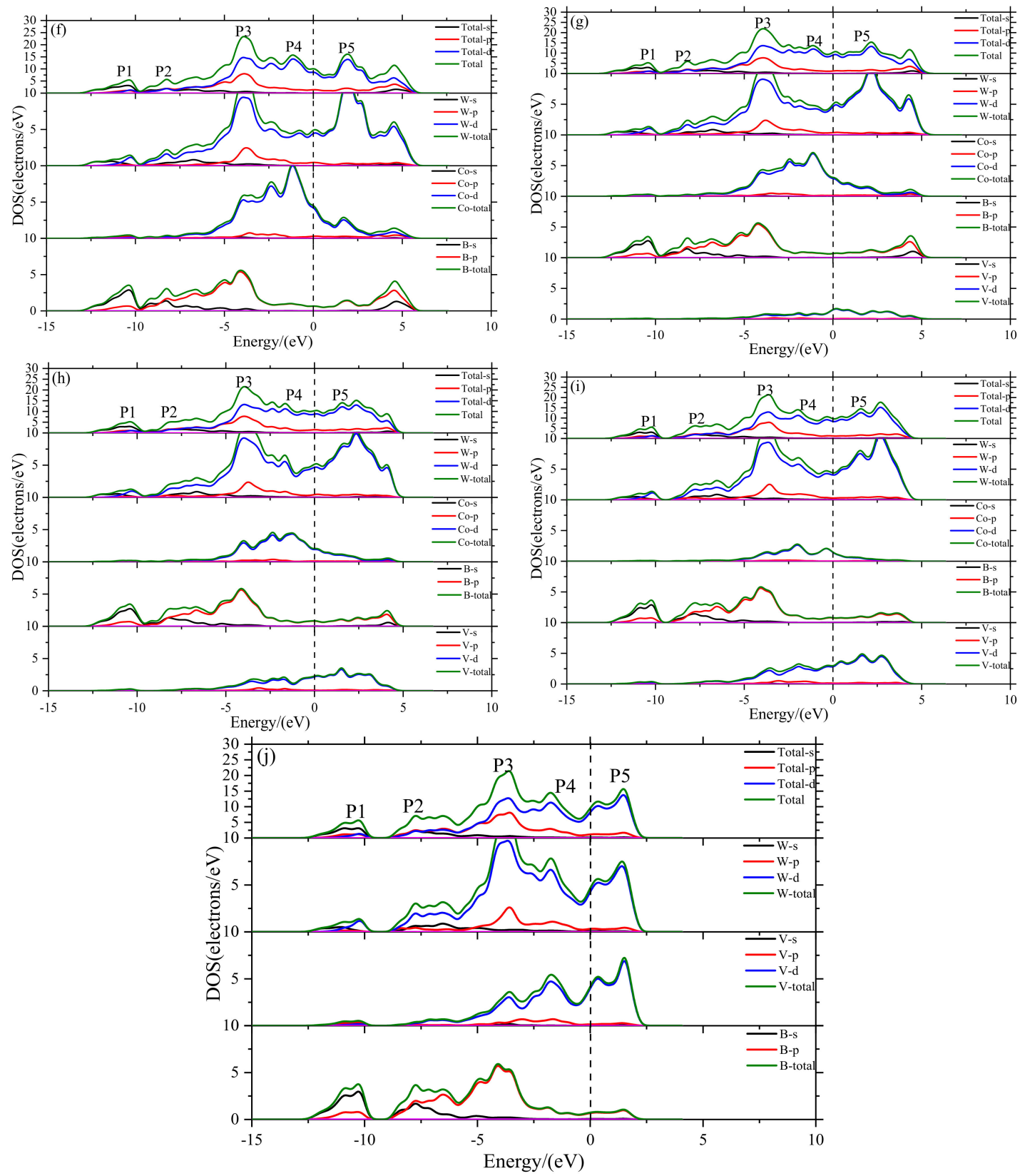

Figure 5. Plots of total and partial density of states of $\mathrm{WCoB}$ with different $\mathrm{V}$ doping content ((f) $\mathrm{W}_{8} \mathrm{Co}_{4} \mathrm{~B}_{8} ;$ (g) $\mathrm{W}_{8} \mathrm{Co}_{3} \mathrm{VB}_{8} ;$ (h) $\mathrm{W}_{8} \mathrm{Co}_{2} \mathrm{~V}_{2} \mathrm{~B}_{8} ;$ (i) $\mathrm{W}_{8} \mathrm{CoV}_{3} \mathrm{~B}_{8} ;(\mathbf{j}) \mathrm{W}_{8} \mathrm{~V}_{4} \mathrm{~B}_{8}$ ).

However, P3, P4 and P5, which are close to the Fermi level, are obviously affected by the V doping content. One of the most obvious features of compounds is the metallic character at Fermi level, and $\mathrm{V}$ doping leads to a significant change at Fermi level and the formation of metal-to-metal bonding between V, Co and W. P3 is composed by Co-3d orbital and W-5d orbital, and the decrement of Co content leads to the decreasing of P3. Because P4 is composed of Co-3d orbital, W-5d orbital and V-3d orbital, the variation of $\mathrm{P} 4$ is minor. However, the influence of Co-3d orbital is greater than V-3d orbital, so the decrement of Co content contributes to the vanishing of P4. P5 is composed of V-3d orbital and W-5d orbital, so increasing the V doping content leads to increasing P5.

By comparing Figures 4 and 5 , it is found that DOS and PDOS of $V$ doping $\mathrm{W}_{2} \mathrm{CoB}_{2}$ are similar to those of $\mathrm{V}$ doping WCoB. We can divide the DOS into several typical peaks, which can be named P1, P2, P3, P4 and P5, located at $-10.4,-7.7,-3.9,-1.2$ and $1.9 \mathrm{eV}$. It is clear that P1 is made up of the strongly hybridized B-2s and W-5d orbitals. Similarly, P2 is composed by B-2p orbital and W-5d 
orbital. So, the values of P1 and P2 change little with increasing V doping content. P1 and P2 exist a resonance peak between B-2s and B-2p orbitals, which means the formation of the B-B covalent bond and contributes to the shear modulus and hardness.

P3 is mainly composed of W-5d orbit with a small amount of Co-3d, V-3d and B-2p orbitals. Because increasing $\mathrm{V}$ content compensates the decreasing Co content, so the intensity of $\mathrm{P} 3$ varies little in different structures. We notice that the intensity of $\mathrm{P} 4$ and $\mathrm{P} 5$ obviously vary in different structures. P4 is mainly affected by Co-3d orbital and P5 is mainly affected by V-3d orbital, so the increasing V doping content leads to a decrease of P4 and an increase of P5. P3, P4 and P5 mainly form metallic bonds, which have a negative influence on the shear modulus.

Based on the DOS and PDOS of $\mathrm{WCoB}$ and $\mathrm{W}_{2} \mathrm{CoB}_{2}$, it is clear that V doping leads to strong hybridization between $\mathrm{B}$ and $\mathrm{V}$ orbitals, which leads to an increase of overlap population. The formation of weaker $\mathrm{B}-\mathrm{V}$ covalent bonds and $\mathrm{W}-\mathrm{V}$ metallic bonds contributes to a decrease of the shear modulus and hardness. The analysis of the electronic structure is consistent with hardness. If $\mathrm{V}$ doping cannot lead to a significantly solid solution or grain refinement [27,28], V doping may not be a suitable choice of transition doping element.

\subsection{Charge Density Difference}

To further explore the bond characterization, the charge density difference of $\mathrm{V}$ doped $\mathrm{WCoB}$ and $\mathrm{W}_{2} \mathrm{CoB}_{2}$ was calculated by first-principle calculation, which is shown in Figures 6 and 7. The charge density differences of $\mathrm{V}$ doped $\mathrm{WCoB}$ and $\mathrm{W}_{2} \mathrm{CoB}_{2}$ are shown along the (010) and (100) plane for different doping contents, respectively. The crucial bonds and atoms are labeled in the figure and the italic atoms are not on the cross-section, which are the projection on the cross-section. Because all the crystal structures have a periodic arrangement, the charge density difference can be visualized by different cross-sections. For the charge density distribution, the red color implies the maximum localization of electrons; the white color means the electron density is almost zero; and the blue color indicates the maximum delocalization of electrons [54].

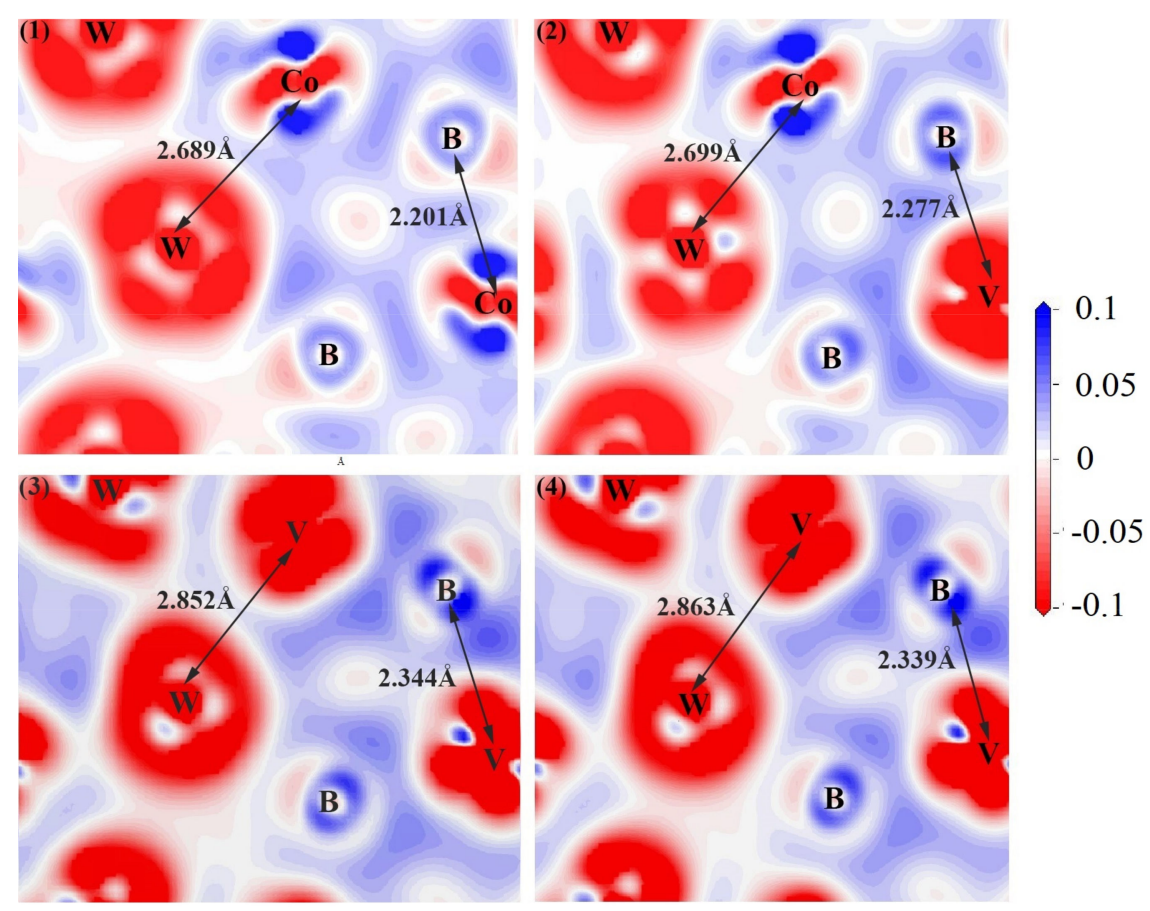

Figure 6. Illustration of charge density difference of $\mathrm{V}$ doped $\mathrm{WCoB}$ at different structure: (1) $\mathrm{W}_{4} \mathrm{Co}_{4} \mathrm{~B}_{4}$-a; (2) $\mathrm{W}_{4} \mathrm{Co}_{3} \mathrm{VB}_{4}$-b; (3) $\mathrm{W}_{4} \mathrm{CoV}_{3} \mathrm{~B}_{4}$-d; (4) $\mathrm{W}_{4} \mathrm{~V}_{4} \mathrm{~B}_{4}$-e. 
It is obvious that $\mathrm{B}-\mathrm{Co} / \mathrm{V}$ covalent bonds and $\mathrm{W}-\mathrm{Co} / \mathrm{V}$ metallic bonds are typical bonds in $\mathrm{V}$ doped WCoB ternary boride. With increasing V doping content, the bond length of B-Co/V covalent bonds increases from 2.201 $\AA$ to $2.339 \AA$. This phenomenon is caused by the larger atom radius of $\mathrm{V}$ atoms, resulting in increases of cell volume. When the doping content reaches up to 33.3 atom $\%, \mathrm{~V}$ atoms will have completely replaced Co atoms, resulting in the increment of symmetry and a slight decrement of bond length. The bond length of W-Co/V metallic bonds obviously increase in the higher $\mathrm{V}$ doping content structure, and the weaker $\mathrm{W}-\mathrm{V}$ metallic bonds lead to the decrement of shear modulus and hardness, which is consistent with the analysis of mechanical properties.

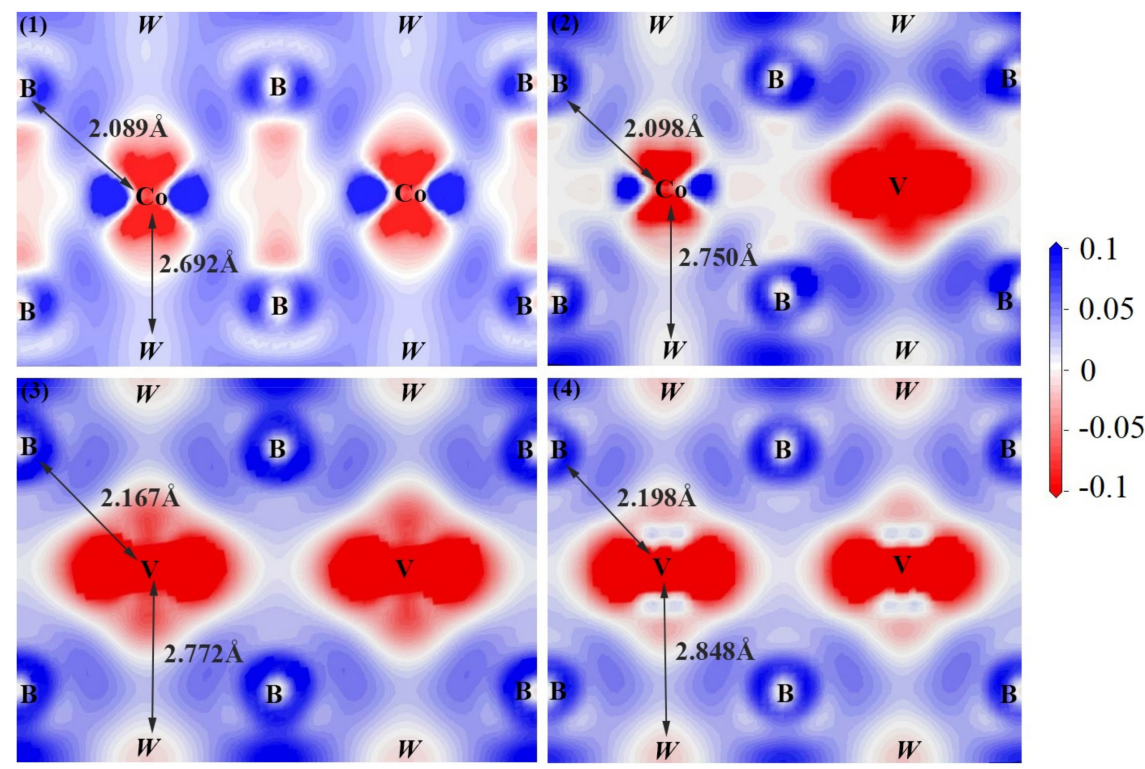

Figure 7. Illustration of charge density difference of $\mathrm{V}$ doped $\mathrm{W}_{2} \mathrm{CoB}_{2}$ at different structure: (1) $\mathrm{W}_{8} \mathrm{Co}_{4} \mathrm{~B}_{8}$-f; (2) $\mathrm{W}_{8} \mathrm{Co}_{3} \mathrm{VB}_{8}-\mathrm{g}$; (3) $\mathrm{W}_{8} \mathrm{Co}_{2} \mathrm{~V}_{2} \mathrm{~B}_{8}-\mathrm{h}$; (4) $\mathrm{W}_{8} \mathrm{~V}_{4} \mathrm{~B}_{8}-\mathrm{j}$.

For $\mathrm{V}$ doped $\mathrm{W}_{2} \mathrm{CoB}_{2}$ ternary boride, the charge density difference is shown in Figure 7, which is mainly formed by $\mathrm{B}-\mathrm{Co} / \mathrm{V}$ covalent bonds and $\mathrm{W}-\mathrm{Co} / \mathrm{V}$ metallic bonds. With increasing $\mathrm{V}$ doping content, the bond lengths of $\mathrm{B}-\mathrm{Co} / \mathrm{V}$ and $\mathrm{W}-\mathrm{Co} / \mathrm{V}$ are up to $2.198 \AA$ and $2.848 \AA$, which indicates that $\mathrm{V}$ doping is harmful to the bond hardness. The formation of weaker bonds leads to the decrease of shear modulus and hardness, which is consistent with the analysis of DOS. When we consider Figures 3 and 4, the $\mathrm{V}$ doping contributes to the formation of $\mathrm{W}-\mathrm{W}$ metallic bonds, indicating the increase of orbital hybridization, which is also consistent with average overlap population analysis.

The calculated charge density difference and electronic structures show that $\mathrm{V}$ doping leads to the formation of weaker B-V covalent bonds and $\mathrm{W}-\mathrm{V}$ metallic bonds with the adjacent atoms. The decrease of the shear modulus and hardness are attributed to increasing bond length. Although population increases slightly in the $\mathrm{V}$ doped structure, it cannot offset the decrease of the number of stronger B-Co covalent bonds and W-Co metallic bonds. Therefore, V doping leads to the decrease of mechanical properties and hardness.

\section{Conclusions}

In summary, comparing with $\mathrm{Cr}$, $\mathrm{Mn}$ doped $\mathrm{WCoB}$ and $\mathrm{W}_{2} \mathrm{CoB}_{2}$, the stability, lattice constants, mechanical properties, average overlap population, hardness, density of states and the charge density difference of $\mathrm{V}$ doped $\mathrm{WCoB}$ and $\mathrm{W}_{2} \mathrm{CoB}_{2}$ ternary boride are calculated and discussed based on the first-principle calculation, which can be drawn as follows.

(1) By analyzing the cohesive energy, formation energy, we can see that all V doped structures are stable. With increasing V doping content, stability increases slightly when the V doping content is up to 16.67 at. $\%$ for $\mathrm{WCoB}$ and 20 at.\% for $\mathrm{W}_{2} \mathrm{CoB}_{2}$. However, the formation energy shows $\mathrm{V}$ 
doped $\mathrm{WCoB}$ and $\mathrm{W}_{2} \mathrm{CoB}_{2}$ ternary boride are harder to form except for the $\mathrm{W}_{4} \mathrm{~V}_{4} \mathrm{~B}_{4}$ structure. The larger atom radius of $\mathrm{V}$ atoms leads to the increase of lattice constants.

(2) The mechanical properties, average overlap population and hardness show $\mathrm{V}$ doping leads to the decreasing of shear modulus and hardness, which is attributed to the weaker $\mathrm{B}-\mathrm{V}$ covalent bonds and $\mathrm{W}-\mathrm{V}$ metallic bonds. Two different hardness models show the shear modulus is closely related to the hardness, and $\mathrm{V}$ doped $\mathrm{W}_{2} \mathrm{CoB}_{2}$ has higher ductility.

(3) The electronic structure of $\mathrm{V}$ doped $\mathrm{WCoB}$ and $\mathrm{W}_{2} \mathrm{CoB}_{2}$ ternary boride is studied by DOS, PDOS and charge density difference. The formation of weaker $\mathrm{B}-\mathrm{V}$ covalent bonds and $\mathrm{W}-\mathrm{V}$ metallic bonds contributes to the orbital hybridization, which is inconsistent with the analysis of mechanical properties and hardness. Moreover, the formation of $\mathrm{W}-\mathrm{W}$ metallic bonds at high $\mathrm{V}$ doping content is harmful to the shear modulus and mechanical properties.

Author Contributions: Funding acquisition, Q.Z.; Methodology, H.Y.; Project administration, H.Y.; Supervision, H.Y., C.Z., R.Z., X.J. and X.Q.; Writing—original draft, T.Z.

Funding: Project supported by the National key research and development program, China (Grant No. 2016YFB0700503), the National High Technology Research and Development Program of China (Grant No. 2015AA034201), the Beijing Science and Technology Plan, China (Grant No. D161100002416001), the National Natural Science Foundation of China (Grant No. 51172018), and the Kennametal Inc., China.

Conflicts of Interest: The authors declare no conflict of interest.

\section{References}

1. Takagi, K.; Ohira, S.; Ide, T.; Watanabe, S.; Kondo, Y. New multiple-boride base hard alloy. Met. Powder Rep. $1987,42,483-484$.

2. Takagi, K. Development and application of high strength ternary boride base cermets. J. Solid State Chem. 2006, 179, 2809-2818. [CrossRef]

3. Yamasaki, Y.; Uchitomi, H.; Ozaki, S.; Komai, M. Corrosion resistance of boride base cermets in a molten aluminum alloy. J. Jpn. Soc. Powder Powder Metall. 1994, 41, 994-998. [CrossRef]

4. Takagi, K. Development of high strength complex boride base hard materials produced by reaction boronizing sintering. J. Jpn. Soc. Powder Powder Metall. 1998, 45, 507-514. [CrossRef]

5. Tashiro, H.; Hirata, K.; Yamasaki, Y.; Takagi, K. Metal injection molding process of $\mathrm{Mo}_{2} \mathrm{FeB}_{2}$ boride base cermets. Mater. Sci. Forum 2007, 534, 377-380. [CrossRef]

6. Wang, H.Q.; Sun, J.S.; Li, C.N.; Geng, S.N.; Sun, H.G.; Wang, G.L. Microstructure and mechanical properties of molybdenum-iron-boron-chromium cladding using argon arc welding. Mater. Sci. Technol. 2016, 32, 1694-1701. [CrossRef]

7. Kuz'Ma, Y.B.; Kripyakevich, P.I.; Chepiga, M.V. Crystal structures of the compounds MoCoB, WCoB, and WFeB. J. Struct. Chem. 1968, 9, 268-269. [CrossRef]

8. Zahariev, Z.T.; Marinov, M.I. Superhard boride layer deposition on a carbide-cobalt hard alloy. J. Alloys Compd. 1993, 201, 1-3. [CrossRef]

9. Sáez, A.; Arenas, F.; Vidal, E. Microstructure development of WCoB-TiC based hard materials. Int. J. Refract. Met. Hard Mater. 2003, 21, 13-18. [CrossRef]

10. Ide, T.; Nakano, K. Effects of $\mathrm{Cr}$ and Mo contents on sintering mechanisms of $\mathrm{Mo}_{2} \mathrm{FeB}_{2}$ base hard alloys. J. Jpn. Soc. Powder Powder Metall. 1989, 36, 38-42. [CrossRef]

11. Pang, X.M.; Zheng, Y.; Wang, S.G.; Wang, Q.H. Effect of Mn on valence-electron structure and properties of hard phase in $\mathrm{Mo}_{2} \mathrm{FeB}_{2}$-based cermets. Int. J. Refract. Met. Hard Mater. 2009, 27, 777-780.

12. Yamasaki, Y.; Uchitomi, H.; Isobe, Y.; Komai, M. Sintering mechanisms of Cr-containing $\mathrm{Mo}_{2} \mathrm{NiB}_{2}$ base hard alloys. J. Jpn. Soc. Powder Powder Metall. 1994, 41, 1037-1041. [CrossRef]

13. Takagi, K.; Koike, W.; Momozawa, A.; Fujima, T. Effects of $\mathrm{Cr}$ on the properties of $\mathrm{Mo}_{2} \mathrm{NiB}_{2}$ ternary boride. Solid State Sci. 2012, 14, 1643-1647. [CrossRef]

14. Takagi, K. Effect of $\mathrm{Mn}$ on the mechanical properties and microstructure of reaction sintered $\mathrm{Mo}_{2} \mathrm{NiB}_{2}$ boride-based cermets. Met. Mater. Int. 2003, 9, 467-471. [CrossRef]

15. Ozdogan, K.; Upadhyay Kahaly, M.; Alshareef, H.N.; Schwingenschlögl, U. Anomalous enhancement of the thermoelectric figure of merit by V co-doping of $\mathrm{Nb}_{-} \mathrm{SrTiO}_{3}$. Appl. Phys. Lett. 2012, 100, 193110. [CrossRef] 
16. Kan, W.H.; Truong, L.; Thangadurai, V. Effect of V-doping on the structure and conductivity of garnet-type $\mathrm{Li}_{5} \mathrm{La}_{3} \mathrm{Nb}_{2} \mathrm{O}_{12}$. Ionics 2015, 21, 373-379. [CrossRef]

17. Mi, X.; Zhang, D.; Wu, Q.; Wang, Z.H. Effect of V doping on magnetic and electrical transport properties of $\mathrm{La}_{0.8} \mathrm{Sr}_{0.2} \mathrm{Co}_{1-x} \mathrm{VxO}_{3}$. Ceram. Int. 2016, 42, 2670-2675. [CrossRef]

18. Thongbai, P.; Pongha, S.; Yamwong, T.; Maensiri, S. Effects of Fe, Ti, and V doping on the microstructure and electrical properties of grain and grain boundary of giant dielectric NiO-based ceramics. Appl. Phys. Lett. 2009, 94, 022908. [CrossRef]

19. Takahashi, M.; Noguchi, Y.; Miyayama, M. Effects of V-doping on mixed conduction properties of bismuth titanate single crystals. Jpn. J. Appl. Phys. 2003, 42, 6222. [CrossRef]

20. Tegel, M.; Schmid, T.; Stürzer, T.; Egawa, M.; Su, Y.; Senyshyn, A.; Johrendt, D. Possible magnetic order and suppression of superconductivity by V doping in $\mathrm{Sr}_{2} \mathrm{VO}_{3}$ FeAs. Phys. Rev. B 2010, 82, 140507. [CrossRef]

21. Joshi, R.; Kumar, P.; Gaur, A.; Asokan, K. Structural, optical and ferroelectric properties of V doped ZnO. Appl. Nanosci. 2014, 4, 531-536. [CrossRef]

22. Hua, N.; Wang, C.; Kang, X.; Wumair, T.; Han, Y. Studies of V doping for the $\mathrm{LiFePO}_{4}$-based Li Ion batteries. J. Alloys Compd. 2010, 503, 204-208. [CrossRef]

23. Hu, B.; Pan, Y.; Wang, Q.; Zhou, H.; Xu, M. Influence of addition element $\mathrm{Cr}$ and V on microstructure and properties of $\mathrm{Mo}_{2} \mathrm{FeB}_{2}$ based cermet. Heat Treat. Met. 2011, 36, $29-32$.

24. Yu, H.; Zheng, Y.; Liu, W.; Zheng, J.; Xiong, W. Effect of V content on the microstructure and mechanical properties of $\mathrm{Mo}_{2} \mathrm{FeB}_{2}$ based cermets. Mater. Des. (1980-2015) 2010, 31, 2680-2683. [CrossRef]

25. Shiota, Y.; Miyajima, Y.; Fujima, T.; Takagi, K. Effect of double addition of V and Cr on the properties of $\mathrm{Mo}_{2} \mathrm{NiB}_{2}$ ternary boride-based cermets. J. Phys. Conf. Ser. 2009, 176, 012046. [CrossRef]

26. Yamasaki, Y.; Nishi, N.; Takagi, K. Effect of Mo content on microstructures and mechanical properties of Mn and V containing $\mathrm{Mo}_{2} \mathrm{NiB}_{2}$ base hard alloys. J. Jpn. Soc. Powder Powder Metall. 2002, 49, 312-317. [CrossRef]

27. Takagi, K.; Yamasaki, Y. Effects of Mo/B atomic ratio on the mechanical properties and structure of $\mathrm{Mo}_{2} \mathrm{NiB}_{2}$ boride base cermets with Cr and V additions. J. Solid State Chem. 2000, 154, 263-268. [CrossRef]

28. Yamasaki, Y.; Nakano, K.; Okada, M. Microstructures and mechanical properties of V-containing $\mathrm{Mo}_{2} \mathrm{NiB}_{2}$ hard alloys. J. Jpn. Soc. Powder Powder Metall. 1995, 42, 438-442. [CrossRef]

29. Yang, F.; Wu, Y.; Han, J.; Meng, J. Microstructure, mechanical and tribological properties of $\mathrm{Mo}_{2} \mathrm{FeB}_{2}$ based cermets with Mn addition. J. Alloys Compd. 2016, 665, 373-380. [CrossRef]

30. Sun, C.; Yu, H.; Liu, W. Microstructure, mechanical properties and first-principles calculations of $\mathrm{Mo}_{2} \mathrm{FeB}_{2}$-based cermets with Mn addition. J. Ceram. Soc. Jpn. 2017, 125, 677-680. [CrossRef]

31. Wang, S.; Pan, Y.; Lin, Y.; Tong, C. Influence of doping concentration on mechanical properties of $\mathrm{Mo}_{2} \mathrm{FeB}_{2}$ alloyed with $\mathrm{Cr}$ and Ni from first-principle calculations. Comput. Mater. Sci. 2018, 146, 18-25. [CrossRef]

32. Lin, Y.H.; Tong, C.C.; Pan, Y.; Liu, W.Y. Elastic properties and electronic structure of $\mathrm{Mo}_{2} \mathrm{FeB}_{2}$ alloyed with $\mathrm{Cr}, \mathrm{Ni}$ and Mn by first-principles calculations. Mod. Phys. Lett. B. 2017, 31, 1750138. [CrossRef]

33. Li, J.; Li, X.; Gao, H.; Peng, D. First-principles study on the electronic structure and elastic properties of $\mathrm{Mo}_{2} \mathrm{NiB}_{2}$ doped with V. Mod. Phys. Lett. B. 2018, 32, 1850065. [CrossRef]

34. Xu, Y.; Pan, Y.; Ke, D.; Yang, L.; Wang, P. Effect of grain growth inhibitor VC on in situ formation of WCoB-TiC-Co multiphase metal-ceramics. Mater. Sci. Technol. 2017, 25, 59-65.

35. Zhang, T.; Yin, H.; Zhang, C.; Qu, X.H.; Zheng, Q.J. Effect of Cr doping on the mechanical properties and electronic structure of WCoB ternary boride by first-principles calculations. Mod. Phys. Lett. B. 2018, 32, 1850240. [CrossRef]

36. Zhang, T.; Yin, H.Q.; Zhang, C.; Qu, X.-H.; Zheng, Q.-J. Effect of Mn doping on mechanical properties and electronic structure of WCoB ternary boride by first-principles calculations. Chin. Phys. B 2018, 27, 107101. [CrossRef]

37. Hohenberg, P.; Kohn, W. Inhomogeneous electron gas. Phys. Rev. 1964, 136, B864. [CrossRef]

38. Kohn, W.; Sham, L.J. Self-consistent equations including exchange and correlation effects. Phys. Rev. 1965, 140, A1133. [CrossRef]

39. Clark, S.J.; Segall, M.D.; Pickard, C.J.; Hasnip, P.J.; Probert, J.; Refson, K.; Payne, M.C. First-principles methods using CASTEP. Z. Kristallogr.-Cryst. Mater. 2005, 220, 567-570. [CrossRef]

40. Kuzma, I.B.; Chepiga, M.V. X-ray Investigation of the Tungsten-Iron-Boron and Tungsten Cobalt-Boron Systems; Lvov State University: Lviv, Ukraine, 1969. 
41. Rieger, W.; Nowotny, H.; Benesovsky, F. Die kristallstruktur von $\mathrm{W}_{2} \mathrm{CoB}_{2}$ und isotypen phasen. Monatshefte für Chemie und verwandte Teile anderer Wissenschaften 1966, 97, 378-382. [CrossRef]

42. Monkhorst, H.J.; Pack, J.D. Special points for Brillouin-zone integrations. Phys. Rev. B 1976, $13,5188$. [CrossRef]

43. Hill, R. The elastic behaviour of a crystalline aggregate. Proc. Phys. Soc. Sect. A 1952, 65, 349. [CrossRef]

44. Born, M. On the stability of crystal lattices. I. Math. Proc. Cambridge Philos. Soc. 1940, 36, 160-172. [CrossRef]

45. Wu, Z.J.; Zhao, E.J.; Xiang, H.P.; Hao, X.F.; Liu, X.J.; Meng, J. Crystal structures and lastic properties uperhard IrN2 and IrN3 from first-principles. Phys. Rev. B 2007, 6, 054115.

46. Lewandowski, J.J.; Wang, W.H.; Greer, A.L. Intrinsic plasticity or brittleness of metallic glasses. Philos. Mag. Lett. 2005, 85, 77-87. [CrossRef]

47. Aouadi, S.M. Structural and mechanical properties of TaZrN films: Experimental and ab initio studies. J. Appl. Phys. 2006, 99, 053507. [CrossRef]

48. Reuss, A. Berechnung der fließgrenze von mischkristallen auf grund der plastizitätsbedingung für einkristalle. ZAMM-J. Appl. Math. Mech./Zeitschrift für Angewandte Mathematik und Mechanik 1929, 9, 49-58. [CrossRef]

49. Zhou, C.T.; Xing, J.D.; Xiao, B.; Feng, J.; Xie, X.J.; Chen, Y.H. First-principles study on the structural properties and electronic structure of $\mathrm{X}_{2} \mathrm{~B}(\mathrm{X}=\mathrm{Cr}, \mathrm{Mn}, \mathrm{Fe}, \mathrm{Co}, \mathrm{Ni}, \mathrm{Mo}$ and $\mathrm{W})$ compounds. Comput. Mater. Sci. 2009, 44, 1056-1064. [CrossRef]

50. Pugh, S.F. XCII. Relations between the elastic moduli and the plastic properties of polycrystalline pure metals. Lond. Edinb. Dublin Philos. Mag. J. Sci. 1954, 45, 823-843. [CrossRef]

51. Chen, X.Q.; Niu, H.; Li, D.; Li, Y. Modeling hardness of polycrystalline materials and bulk metallic glasses. Intermetallics 2011, 19, 1275-1281. [CrossRef]

52. Gao, F.; He, J.; Wu, E.; Liu, S.; Yu, D.; Li, D.; Zhang, S.; Tian, Y. Hardness of covalent crystals. Phys. Rev. Lett. 2003, 91, 015502. [CrossRef] [PubMed]

53. Yu, H.B.; Wang, W.H.; Bai, H.Y. An electronic structure perspective on glass-forming ability in metallic glasses. Appl. Phys. Lett. 2010, 96, 081902.

54. Xu, W.W.; Han, J.J.; Wang, Y.; Wang, C.P.; Liu, X.J.; Liu, Z.K. First-principles investigation of electronic, mechanical and thermodynamic properties of $\mathrm{L} 12$ ordered $\mathrm{Co} 3(\mathrm{M}, \mathrm{W})(\mathrm{M}=\mathrm{Al}, \mathrm{Ge}, \mathrm{Ga})$ phases. Acta Mater. 2013, 61, 5437-5448. [CrossRef] 